\title{
Modernising social care services for older people: scoping the United Kingdom evidence base
}

\author{
SALLY JACOBS*, CHENGQIU XIE $\dagger$, SIOBHAN REILLY $\dagger$, \\ JANE HUGHES $\dagger$ and DAVID CHALLIS $\dagger$
}

\begin{abstract}
In common with other developed countries at the end of the 2oth century, modernising public services was a priority of the United Kingdom (UK) Labour administration after its election in I997. The modernisation reforms in health and social care exemplified their approach to public policy. The authors were commissioned to examine the evidence base for the modernisation of social care services for older people, and for this purpose conducted a systematic review of the relevant peer-reviewed UK research literature published from I990 to $200 \mathrm{I}$. Publications that reported descriptive, analytical, evaluative, quantitative and qualitative studies were identified and critically appraised under six key themes of modernisation: integration, independence, consistency, support for carers, meeting individuals' needs, and the workforce. This paper lists the principal features of each study, provides an overview of the literature, and presents substantive findings relating to three of the modernisation themes (integration, independence and individuals' needs). The account provides a systematic portrayal both of the state of social care for older people prior to the modernisation process and of the relative strengths and weaknesses of the evidence base. It suggests that, for evidence-based practice and policy to become a reality in social care for older people, there is a general need for higher quality studies in this area.
\end{abstract}

KEY WORDS - modernisation, social care, evidence-based policy, systematic review.

\section{Modernisation at the end of the 2oth century}

The latter half of the 2oth century witnessed a reshaping of government and public services across the western world (Organisation for Economic Co-operation and Development (OECD) 2003). By the early ig8os, the

* School of Pharmacy and Pharmaceutical Sciences, University of Manchester, UK.

$\dagger$ Personal Social Services Research Unit, University of Manchester, UK. 
post-I945 monopoly of central provision was being called into question, with concerns raised over quality and choice within public services and the increasing financial burden they placed on governments. A number of administrations of the I980s and I99os (as in the United Kingdom (UK), New Zealand and Australia) adopted management theories from the private sector and applied them in a raft of public-sector reforms (Hood I99I), but these did not take into account the complexity of public services when applying management processes and 'created a greater need for coordination while reducing governmental ability to co-ordinate' (Rhodes 2000).

In the UK, the self-styled modernisation reforms of the incoming Labour administration of 1997 drew heavily upon the neo-liberal reforms of the preceding Conservative administrations whilst attempting to overcome their failings. The modernisation reforms in health and social care exemplified this approach to public policy. For example, The New NHS: Modern-Dependable White Paper stated, 'There will be no return to the old centralised command and control systems of the I970s ... but nor will there be a continuation of the divisive internal market system of the I990s. ... Instead there will be a "third way" of running the NHS (National Health Service) - a system based on partnership and driven by performance' (Cm 3807 1997: para 2.I-2.2). ${ }^{1}$ In the social care White Paper, Modernising Social Services, published the following year, the emphasis was very much on empowering the service user: 'Our third way for social care moves the focus away from who provides the care, and places it firmly on the quality of services experienced by, and outcomes achieved for, individuals and their carers and families' (Cm 4I69 I998: para I.7).

Thus the consumerist approach underpinning the Conservative reforms (Cm I599 I99I), which promoted the direct accountability of public services to the service user and the idea that service quality could ultimately be enhanced through consumer choice, was still clearly evident in the modernisation reforms of the Labour government (Newman 200I). Characteristic of these reforms, however, was their particular emphasis on partnerships and joined-up working (Cowell and Martin 2003). One important aspect of the modernisation of public services in the UK was a pragmatic emphasis on 'what counts is what works'. A belief in evidencebased policy making was evident in key modernisation policy documents, for example, the 1999 White Paper Modernising Government, which stated: 'Government should regard policy making as a continuous, learning process, not as a series of one-off initiatives. ... We will ensure that all policies and programmes are clearly specified and evaluated, and the lessons of success and failure are communicated and acted upon' (Cm 4310 1999: I7). 


\section{Background to the study}

In 2002, as part of its stated commitment to evidence-based policy making, the UK Department of Health (DH) commissioned a review of the delivery, commissioning and impact of social care services for four adult user groups (with mental health problems, with physical and/or sensory impairments, with a learning disability, and older people) before the influence of modernisation, with the aim of producing a baseline from which to measure the success or otherwise of the reforms (DH 2007a). As part of this, four systematic literature reviews were undertaken to find, assess and synthesise empirical studies of adult social-care services. The aim of this paper is to provide an overview of the peer-reviewed research literature pertaining to the social care of older people in the UK from the introduction of the community care reforms of the early iggos to the New Labour reforms at the turn of the 2 ist century. In particular, it will describe the evidence base that supported the underlying themes of the modernisation process as applied to older people's services in social care. The paper begins with an analysis of UK modernisation policy as applied to social care for older people, providing a framework for the findings. After describing the review methodology, the findings are presented in two ways. Firstly, an overview of the coverage, quality, methods used and overall strengths and weaknesses of the research literature is presented. Secondly, a synthesis of selected substantive findings is presented within the modernisation framework. A full report of the findings may be found in Challis et al. $(2004 a)$.

\section{Modernising social care for older people in the UK}

To meet the needs of the research commission, the prevailing themes of the modernisation reforms for adult social care were derived from an analysis of key UK policy and legislation documents. Six themes were thus derived, associated with 20 areas of reform (I9 in the case of older people's services: see Table 4 ).

\section{Integrated health and social care}

The compartmentalisation of health and social care services in many countries is rooted in the regulation of health care by either a national health system (as in the UK and Nordic countries) or a social insurance system administered by central government (as in Germany and The Netherlands), whereas social care is overseen by local or regional 
government (Leichsenring 2003). Recognition of the need to achieve greater integration of health and social care in these countries is by no means new, but rather has been a recurrent policy theme for 50 years. In I997, however, the incoming UK Labour government made one of its top priorities to bring down the 'Berlin Wall' that divides health and social services to create a system of integrated care that puts users at the centre of service provision ( $\mathrm{Cm} 4 \mathrm{I} 69$ 1998: 97). Nowhere was this more apparent than in its health and social-care policy proposals, those for older people's services being no exception. Modernisation has entailed a series of initiatives: the single assessment process (DH 2002); Health Act I999 flexibilities; NHS Care Trusts (Cm 4818-I 2000); a health and social care model for the management of long-term conditions ( $\mathrm{DH}$ 2005); and most recently, the joint health and social care White Paper for community services, Our Health, Our Care, Our Say (Cm 6737 2006).

\section{Independence}

Townsend (I98I) argued that the use of long-stay hospital provision for older people and continued investment in the residential care market had contributed towards the structural dependency of older people. Subsequently, many developed-country governments invested in community-based alternatives to institutional care, to promote the independence of older people and to release hospital bed-days (Jacobzone 2000). Independence emerged as an enduring feature of British policies for modernising social care services. For frail older people, initiatives in this regard focused primarily on shifting the location of care away from hospitals and care homes and into people's own homes (Cm 4I69 I998; Cm 4818-I 2000; DH 200I; Cm 6737 2006). Policy developments in four constituent areas were apparent: hospital discharge, rehabilitation, the provision of care at home or in home-like environments, and direct payments.

Whilst the closure of long-stay hospital provision for older people predated the recent drive to modernise social care, it is pertinent to this review because of the legacy of community-based services that were its substitute. Subsequently, discharge from acute hospital settings has become a prominent concern of modernisation policies in the UK and elsewhere (Australia, Department of Community Services and Health I99I; Ikegami, Yamauchi and Yamada 2003). In the UK, the Griffiths Report (I988) put forward 'care at home' as a key principle and objective of community care - it has guided the development of services ever since. For example, Modernising Social Services stated the following national objective for social services: 'To enable adults assessed as needing social 
care support to live as safe, full and as normal a life as possible, in their own home wherever feasible' (Cm 4I69 I998: III). Linked to the emphasis on care closer to home, the development of rehabilitation services for older people was promoted. For example, 'active recovery and rehabilitation services' was a core dimension of the development of intermediate care services (broadly defined as services promoting independence, facilitating hospital discharge and/or preventing unnecessary hospital admission), and one of the standards set by the National Service Framework for Older People (NSFOP) (DH 200I) that set out the process for modernising older people's services. A final area of enquiry concerned the introduction of direct payments. Cash-for-care schemes that offer cash payments or vouchers in lieu of services have been introduced by the United States and several European countries (Ungerson 2004). In the UK, direct payments were introduced by local authorities with the aim of giving users freedom and independence in running their own lives $(\mathrm{DH}$ $2003 a)$.

\section{Consistency}

Modernisation policies in the UK sought to standardise the response of local authorities in respect of service provision, and three specific initiatives were apparent: the development and implementation of eligibility criteria; extending the range of services available to meet assessed need; and developing effective and transparent costing and charging procedures. The idea of social-care eligibility criteria originated in the White Paper Caring for People (Cm 849 I989), and subsequently their purpose was described as to inform users 'about what sorts of people with what kinds of need qualify for what types of service' (Cm 4I69 I998: 23). The community care reforms of the early ig9os required local authorities to commission and purchase social care, not to be the primary provider, and thereby to make maximum possible use of voluntary-sector and privatesector provision, but one consequence of this approach has been the fragmentation and uneven development of services. Thus, extending the range of services available to meet assessed need for social care was accorded importance in modernisation policy initiatives such as Modernising Social Services (Cm 4I69 I998) and the NSFOP (DH 200I). The principle of charging for social-care services predates both the modernisation agenda and the I993 community care reforms. Variations in charges for various user groups within and between authorities have since been noted $(\mathrm{Cm}$ 4I69 I998; Audit Commission 2000). Subsequently it was required that the charges are part of the written record of the individual client's care plan (DH 2002). 


\section{Support to carers}

The care provided to older people through informal mechanisms is an essential backdrop to community care policies in the UK and other industrialised nations (Gibson, Gregory and Pandya 2003). The division of responsibility between state and family appears to stem from both the culture and traditions of a country as well as social policy. For example, in Scandinavian countries and The Netherlands, community service provision is better developed than in central and southern European countries, where family obligations are either assumed or else legislated for (Daatland 200I). During the last three decades of the 2oth century, UK policy increasingly recognised the contribution of informal carers to the care of vulnerable adults (Cmnd 4683 1971; Cmnd 6233 1975; Cmnd 8173 I98I). Carers were accepted as service users in their own right by the Carers (Recognition and Services) Act 1995, and the first UK national strategy for carers was launched four years later (DH i999).

\section{Making sure services fit individuals' needs}

The norm of fitting care and services to individuals' needs has long been evident in the professional literature (e.g. Warren i946). Based on early experiments in case management in the United States (US) and UK (Huxley 1993), care management became a key change in the UK community care reforms, being identified as a means of providing an effective method of targeting resources and planning services to meet individual's specific needs (Cm 849 I989). It continued to be endorsed in modernisation policies for older people (DH 200I) and in social services more widely (Cm 4169 1998). Modernising Social Services also provided guidance to local authorities about how best to commission services. The desired outcome was that commissioning would 'help to ensure that services meet people's specific individual needs, and that groups with particular needs, such as people from ethnic minorities, are better served' (Cm 4I69 I998: 36 ).

The debate about the value of low-level preventative services has been a longstanding concern, evident in From Home Help to Home Care (Social

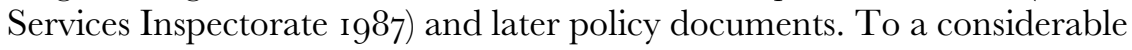
extent, however, prevention was given a relatively low priority immediately after the introduction of the community care reforms, for the emphasis was then on targeting resources to those in greatest need $(\mathrm{Cm} 849$ I989). A focus on 'prevention' has returned in recent policy documents (Cm 6737 2006) and been expressed in older people's services in the form of 'Partnerships for Older People Projects' (Cm 6499 2005: para 8.6). At the other end of the care spectrum, the need to target resources - by which frail older people with complex needs receive care of different intensity 
and content to that received by service users with less complex needs currently finds expression in the single assessment process, which specifies four levels of assessment in relation to need (DH 2002).

\section{The workforce}

In common with other developed countries (Hussein and Manthorpe 2005), UK policy has recently emphasised the recruitment and retention of staff in the social care of frail older people (DH 200I). In A Quality Strategy for Social Care, the importance of the workforce was reiterated: 'Social care staff comprise the greatest asset services possess' (DH 2000: 9). It argued that to develop a competent workforce for the modernising agenda requires (amongst other things) improved recruitment and job retention. Furthermore, in Modernising Social Services, an objective for social services was 'to ensure that social care workers are appropriately skilled, trained and qualified, and to promote the uptake of training at all levels' (Cm 4r69 I998: III).

\section{Methodology of the literature review}

The review systematically identified, selected, extracted and appraised information from descriptive, evaluative, qualitative and quantitative peer-reviewed research articles that examined social care services for older people in the UK and were published between 1990 and 2004. The key features of the methodology are summarised here, but fuller details may be found in Reilly et al. (2008).

\section{Literature searches}

Searches of io diverse electronic databases were carried out between November 2003 and May 2004. ${ }^{2}$ The main search terms included several for social and community care and others for ageing and older people's services (Table I). To supplement the electronic searches, a number of general journals and those specific to old age ${ }^{3}$ were hand-searched for relevant research papers published during 1990 to 2004. The reference lists of the retrieved articles were also scanned.

\section{Inclusion and exclusion criteria}

The remit for the review from the commissioners was exceedingly wide - to describe the state of social-care services for older people at the turn of the 2ist century. Several criteria were required to accommodate 
T А в L E I. Keywords and search terms employed in electronic searches

\begin{tabular}{|c|c|c|c|}
\hline $\begin{array}{l}\text { Population or } \\
\text { target group }\end{array}$ & Service area & Type of article/study & Location \\
\hline $\begin{array}{l}\text { Inclusion terms: } \\
\text { aged } \\
\text { ageing } \\
\text { aging } \\
\text { elder* } \\
\text { elder* care } \\
\text { elder* people } \\
\text { old age } \\
\text { old* people }\end{array}$ & $\begin{array}{l}\text { community care } \\
\text { community service* } \\
\text { home care service* } \\
\text { social care } \\
\text { social service* } \\
\text { social work service* } \\
\text { social work* }\end{array}$ & $\begin{array}{l}\text { applied research/community care } \\
\text { projects/evaluat*/evidence based } \\
\text { practice/follow up studies/literature } \\
\text { reviews/policy evaluation/program*/ } \\
\text { project*/research/research methods/ } \\
\text { research projects/research reports/ } \\
\text { review*/service evaluation/social } \\
\text { research/stud*/survey*/systematic } \\
\text { reviews/trial }\end{array}$ & \\
\hline $\begin{array}{l}\text { Exclusion terms: } \\
\text { child* } \\
\text { drug abuse } \\
\text { drug* } \\
\text { HIV } \\
\text { substance abuse } \\
\text { substance* }\end{array}$ & $\begin{array}{l}\text { Clinical } \\
\text { Medicaid } \\
\text { medication }\end{array}$ & $\begin{array}{l}\text { book review } \\
\text { circular } \\
\text { PhD thesis }\end{array}$ & $\begin{array}{l}\text { USA } \\
\text { US } \\
\text { America* } \\
\text { Canada } \\
\text { Australia }\end{array}$ \\
\hline
\end{tabular}

Note: * indicates any suffix or none.

\section{T A B L E 2. Inclusion and exclusion criteria applied in selecting papers for review}

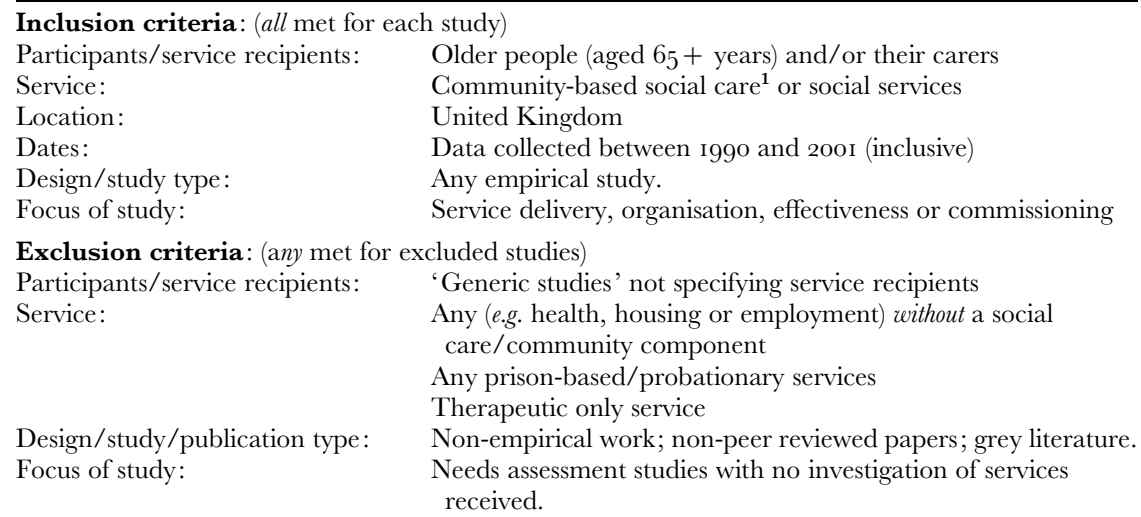

Note: I. Social care was defined as services provided, commissioned, funded or facilitated by the lead social services agency in a locality.

the breadth and focus of the review and to keep the task manageable (Table 2). The inclusion and exclusion criteria were applied at two stages. At the first stage, the title and abstract (if available) were examined by the lead author of this paper (SJ). If it was expected that the study would meet 
T A в L E 3. Assessing methodological quality

\begin{tabular}{|c|c|}
\hline Data extraction sheet items & Responses \\
\hline I. Is the research question clear? & yes/no \\
\hline $\begin{array}{l}\text { 2. Given the research questions and subject matter (and not necessarily other } \\
\text { factors, e.g. resources, ethics, timescale, experience of researchers), was the } \\
\text { design of the study the most appropriate? }\end{array}$ & yes/no/unclear \\
\hline $\begin{array}{l}\text { 3. Is the sample strategy adequate to draw generalisable or transferable } \\
\text { conclusions from the study? (consider issues of sample size, number of } \\
\text { sites/ locations, power calculations, 'representativeness', attrition and } \\
\text { non response)? }\end{array}$ & yes/no/unclear \\
\hline $\begin{array}{l}\text { 4. Is there sufficient detail given on the nature of the intervention/ service/ } \\
\text { comparison intervention/ context/setting (including subjects), so that the } \\
\text { reader can relate the findings to other settings? }\end{array}$ & yes/no/unclear \\
\hline $\begin{array}{l}\text { 5. Were both the data collection and analysis rigorously conducted (include the } \\
\text { study's description of data analysis)? }\end{array}$ & yes/no/unclear \\
\hline $\begin{array}{l}\text { 6. Are enough data presented to permit independent judgement? Are you able } \\
\text { to interpret the results? }\end{array}$ & yes/no/unclear \\
\hline \multirow{2}{*}{$\begin{array}{l}\text { 7. Is the conclus } \\
\text { Overall score }\end{array}$} & yes/no/unclear \\
\hline & Range $0-7$ \\
\hline
\end{tabular}

Note: 'yes' $=\mathrm{I}$; no, unclear $=0$.

the inclusion criteria, the full text of the article was obtained. At the second stage, the full article was examined and the full criteria applied. Any queries at both stages were addressed collectively by the review team.

\section{Data extraction and assessment of methodological quality}

Each paper that met all the inclusion criteria (and none of the exclusion criteria) was abstracted to elicit the following information: study aims, research paradigm, study design, methods of data collection, dates, scope of the study, unit of analysis, key findings and implications for policy and ratings of methodological quality. ${ }^{4}$ Most of this information was coded using pre-determined categories that were based on work by Boruch (I997), Gray (I997), and Petticrew and Roberts (2003). In addition, each paper was categorised by its ability substantially to inform or address the six themes of modernisation outlined above.

The scientific quality of papers was assessed in relation to a set of seven a priori quality attributes that measured internal, descriptive, construct and external validity (Table 3). Although measures of methodological quality for designs other than randomised-controlled trials (RGTs) are available (Mays and Pope 2000; Spencer et al. 2003), none were suitable for a high volume review that included diverse research designs. Aided by these sources and the general evaluation literature, the research team devised hybrid criteria. Positively-rated items (response $=$ 'yes') were assigned one point each and these were summed into a total score. The maximum 
possible score was ' 7 ', denoting high methodological quality. The internal consistency of this scoring system was examined using Cronbach's alpha, the overall score of 0.56 indicating acceptable internal consistency. ${ }^{5}$ Each paper included in the study was read, extracted for information and rated by the lead researcher for this review (SJ). The team of reviewers met regularly to compare and discuss ratings across the four reviews being simultaneously conducted to maximise reliability.

\section{Data management, synthesis and reporting}

The unit of analysis was the research paper rather than the study because some studies tackled several research questions and generated multiple publications, sometimes under different authorship. This report opens with an overview of the coverage, study quality and methods used, and a summary account of the strengths and weaknesses of the evidence. Then, reflecting the heterogeneity of the studies, a narrative synthesis rather than a quantitative report is provided (Mays, Roberts and Popay 200I). The scope of the review makes it impossible to describe or even list all the included studies (for which see Challis et al. 2004a). Instead, literature under three of the six modernisation themes is discussed: integration, independence and individuals' needs. These three were selected for three reasons: (i) their dominance in the UK older people's social-care modernisation policies; (ii) their international relevance - many OECD countries have framed policies to promote deinstitutionalisation and the community care of frail older people (Anderson and Hussey 2000), and that require integrated systems of service delivery (Johri, Belland and Bergman 2003); and (iii) the high volume of identified literature from which the state of services before modernisation can be described. To exemplify, whilst the theme support to carers met criteria (i) and (ii), the sparse research evidence prevented a full analysis of these services. Similarly, consistency in service provision may have a growing evidence base but the coverage is mainly limited to the UK. Furthermore, the narrative synthesis concentrates on the higher quality studies - those scoring ' 5 ' (the median) or above using the seven-point rating described above.

\section{Limitations of the review}

Before presenting the findings, it is important to note the limitations of the review. It was not a standard clinical or health-services research review with a narrow focus on the effectiveness or cost-effectiveness of a particular intervention or group of interventions. Difficulties therefore arose with the scope, synthesis and reporting, and these required modifications to the standard methodology of systematic reviews (discussed more fully in 
Reilly et al. 2008). Firstly, the remit of the review was to describe social care at the end of the 2oth century, before recent modernisation policies had had a full impact on services. To capture research evidence from the beginning of the community care reforms to the emergence of the modernisation agenda, a specific time frame was therefore applied - between the NHS and Community Care Act 1990 and the Health and Social Care Act $200 I$. Studies conducted outside this period were not included, which explains some gaps, e.g. more recently published evidence on direct payments for older people's services.

Secondly, we fully recognise that much research evidence on social care has been published in books and reports rather than journal papers. Given the available resources, however, it would have been impossible to review systematically the non-journal literature. Pragmatically selecting peerreviewed publications did however impose a rough quality-control filter (although clearly there are many exceptions). Thirdly, the review was only concerned with services specifically for older people. In the course of the review, however, some articles were identified that investigated social care in general but that were relevant to older people's services. Such studies were not included as they did not meet the original inclusion criteria and, most importantly, the search strategies were not designed to identify all 'generic' articles. Given the review's design, some relevant publications will have been missed; this influenced our decision not to report work on the workforce theme.

One final consideration regards the study quality rating applied to each publication. A scoring system was devised which had to be applicable to both qualitative and quantitative studies, as well as those with mixed methods. There were difficulties, however, primarily as a result of the different traditions and styles of reporting by researchers using the different paradigms and from different disciplines. Qualitative papers as a whole scored less than quantitative papers, with mixed methods papers in between. This did not, however, always reflect less rigour in the research process but sometimes a failure to report in sufficient detail one or more of: the methods of data collection and analysis, information about the sample or sampling; and the findings. It was such deficiencies that prevented a full judgement of quality (not the reviewers' methodological bias, for we have used and published qualitative and quantitative research). It is debatable whether qualitative research should be reported using the same scientific method as, for example RCTs (Mays and Pope 200o). However, papers that do not enable the reader to form their own judgement of the quality of a study also prevent the presented evidence being used to inform further research or, more importantly, to improve services and inform policy. 
T A в L E 4. Peer-reviewed publications addressing the themes of modernisation and their associated areas of enquiry

\begin{tabular}{|c|c|c|c|c|}
\hline Modernisation themes and inquiry themes & Number & $\%$ & Number $^{1}$ & $\%$ \\
\hline Integrated health and social care: & & & 59 & 25 \\
\hline Developing partnership working & 7 & 3 & & \\
\hline Joined-up services & 53 & 23 & & \\
\hline Independence: & & & 53 & 23 \\
\hline Hospital discharge from long-stay settings & 8 & 3 & & \\
\hline Hospital discharge from acute-care settings & 20 & 9 & & \\
\hline Work opportunities ${ }^{2}$ & - & - & & \\
\hline Rehabilitation & 7 & 3 & & \\
\hline Care at home or in home-like environments & 24 & IO & & \\
\hline Direct payments & 3 & I & & \\
\hline Consistency: & & & 37 & I6 \\
\hline Eligibility criteria and access to services & 5 & 2 & & \\
\hline Range of services & I8 & 8 & & \\
\hline Charges to users & I4 & 6 & & \\
\hline Support to carers: & & & 23 & IO \\
\hline Knowledge of entitlement & I & $<\mathrm{I}$ & & \\
\hline Assessment and care plan & 8 & 3 & & \\
\hline Service provision & I8 & 8 & & \\
\hline Making sure services fit individuals' needs: & & & 156 & 67 \\
\hline Care management (including assessment) & 79 & 34 & & \\
\hline Service commissioning & $8 \mathrm{I}$ & 35 & & \\
\hline Preventative services & 5 & 2 & & \\
\hline Targeting assistance & 15 & 6 & & \\
\hline Workforce: & & & 25 & II \\
\hline Recruitment and retention & Io & 4 & & \\
\hline Training & I7 & 7 & & \\
\hline
\end{tabular}

Notes: I. Aggregates of sub-totals exceed totals due to multiple categorisation of some review papers. 2. Not operationalised in older people's review.

\section{Findings: an overview of the literature}

From just over 7,00o retrieved references, 234 peer-reviewed papers that reported UK studies conducted between 1990 and 200 of social care in older people's services met the inclusion criteria. Almost one-fifth were identified by hand searches of relevant journals and the reference lists from other publications. Each study was categorised according to the modernisation theme(s) and area of enquiry(s) that it informed (Table 4). Two-thirds of these studies addressed the theme of making sure services fit individuals' needs, in particular care management and commissioning, but notably only io per cent addressed support to carers. The majority $(76 \%)$ of the publications were descriptive and addressed the scope of a particular problem or needs, the services provided and the process of service delivery. By comparison, far fewer (33\%) measured the impact of services for 
T A B L E 5. Assessment of methodological quality of studies by modernisation theme

\begin{tabular}{lcccc}
\hline & \multicolumn{4}{c}{ Quality scores } \\
\cline { 2 - 5 } Modernisation theme & $\mathrm{O}^{-3} \%$ & $4-5 \%$ & $6-7 \%$ & Mean \\
\hline Integrated health and social care & 32 & 24 & 44 & 4.6 \\
Independence & 28 & 43 & 30 & $4 \cdot 5$ \\
Consistency & II & 64 & 25 & 4.8 \\
Support to carers & 30 & 48 & 22 & $4 \cdot 4$ \\
Making sure services fit individuals' needs & 24 & 37 & 39 & 4.8 \\
Workforce & $2 \mathrm{I}$ & 54 & 25 & $4 \cdot 4$ \\
All publications & 23 & 39 & 38 & 4.8 \\
\hline
\end{tabular}

T A B L E 6. Frequencies of attainment of dimensions of methodological quality

\begin{tabular}{lcc}
\hline Dimension of quality & Number & Per cent \\
\hline Clear research question & 230 & 98 \\
Appropriate design & 201 & 86 \\
Generalisable & 68 & 29 \\
Sufficient detail on context/setting/intervention & 164 & 70 \\
Rigorous data collection/analysis demonstrated & 129 & 55 \\
Presentation of results & $16 \mathrm{I}$ & 69 \\
Conclusion justified & I58 & 68 \\
\hline
\end{tabular}

Note: Sample size, 234 publications.

older people in terms of effectiveness, cost effectiveness, acceptability or satisfaction. It is striking that only io papers reported RGTs, and another four quasi-experimental trials. Furthermore, because there have been so few RCTs, no systematic reviews were found. The studies represent a wide range of research paradigms, from in-depth qualitative investigations of service users' experiences, to economic modelling of service costs. Onehalf $(52 \%)$ of the studies were exclusively quantitative, over one-quarter $(27 \%)$ were entirely qualitative, and the remainder (2I \%) used a combination of methods.

The methodological quality of the included studies is presented in Tables 5 and 6 . It is important to bear in mind the distributions of quality scores for each modernisation theme when considering the review's findings. In particular, it is notable that 23 per cent of the studies were of relatively poor methodological quality (scored between ' 0 ' and ' 3 ', see Table 5), and less than one-third were assessed as being generalisable or transferable to a wider population (Table 6). Noteworthy also is the fact that almost one-half of the publications failed to demonstrate rigorous data collection or analysis. Whilst for many studies this reflected low scientific rigour, others failed to score positively through poor reporting. 
T A B L E 7. Summary of the strengths and weaknesses of the evidence supporting the modernisation of social care for older people

\begin{tabular}{|c|c|c|}
\hline Themes & Strong evidence & Weak/no evidence \\
\hline Integration & $\begin{array}{l}\text { Primary Care Trusts were slow to } \\
\text { engender integrated working } \\
\text { practices } \\
\text { Integrated service delivery more } \\
\text { advanced in old age mental health } \\
\text { services than mainstream older } \\
\text { people's services }\end{array}$ & $\begin{array}{l}\text { Benefits for quality of service } \\
\text { delivery/benefits to users of } \\
\text { integrated organisations } \\
\text { Benefits of integrated service delivery } \\
\text { Generic hands-on care worker }\end{array}$ \\
\hline Independence & $\begin{array}{l}\text { Organisational issues, often } \\
\text { involving co-ordination between } \\
\text { health and social services, main } \\
\text { cause of delayed discharge } \\
\text { Few local authorities offer intensive } \\
\text { care management, despite strong } \\
\text { evidence for its cost-effectiveness }\end{array}$ & $\begin{array}{l}\text { Social services contribution to } \\
\text { intermediate care } \\
\text { Impact of day care } \\
\text { Use of direct payments with older } \\
\text { people }\end{array}$ \\
\hline Consistency & $\begin{array}{l}\text { Eligibility criteria variable within } \\
\text { and between local authorities and } \\
\text { becoming tighter } \\
\text { Barriers to service use for people } \\
\text { from ethnic minorities } \\
\text { Inequitable treatment of self- } \\
\text { funded admissions to care homes }\end{array}$ & $\begin{array}{l}\text { Extension of range of services to } \\
\text { meet assessed need }\end{array}$ \\
\hline Support to carers & $\begin{array}{l}\text { Separate carers' assessments } \\
\text { uncommon and neglect } \\
\text { emotional needs } \\
\text { High levels of unmet need }\end{array}$ & $\begin{array}{l}\text { Cost-effectiveness of different modes } \\
\text { of carer support }\end{array}$ \\
\hline Individuals' needs & $\begin{array}{l}\text { Barriers to a needs-led/user- } \\
\text { focused approach to assessment } \\
\text { Predictors of service use/care home } \\
\text { admissions }\end{array}$ & $\begin{array}{l}\text { Cost-effectiveness of different forms } \\
\text { of care management } \\
\text { Cost-effectiveness of preventative/ } \\
\text { low-level service provision }\end{array}$ \\
\hline Workforce & $\begin{array}{l}\text { Stress levels are high within social } \\
\text { work profession } \\
\text { Recruitment and, to a lesser extent } \\
\text { retention, a problem in the care } \\
\text { sector }\end{array}$ & $\begin{array}{l}\text { Outcomes of training } \\
\text { programmes in social care }\end{array}$ \\
\hline
\end{tabular}

The findings concerning study methodology and quality from this review, and for the parallel reviews for the other adult user groups, are discussed in greater depth elsewhere (Reilly et al. 2008). A summary of the key strengths and weaknesses of the evidence supporting UK modernisation policies for older people's services is presented in Table 7. A strong evidence base may be down to one or two highly generalisable, good quality studies or to a larger number of small studies of lesser quality all of which reached the same or similar conclusions. Instances of a 'weak' or 'null' evidence base arise when only one or two methodologically weak studies were identified or none at all. 


\section{Details of the studies}

The following section of the paper syntheses the key substantive findings from the reviewed papers that are categorised under the themes of integration, independence and individuals' needs. As explained above, high quality articles that scored ' 5 ' or above (on the seven-point scale) were selected for this paper and their key features are presented in Table 8 . Where these are cited below, the figures in parentheses refer to the study reference numbers in Table 8. On the few occasions where studies of lesser quality are cited, these are referred to in the conventional manner, as are papers not included in the literature review.

\section{Integrated health and social care}

Beginning with evidence of partnership working, the identified studies demonstrate that, with particular reference to services for older people, partnerships between social services and the NHS were variable and progressing slowly by the end of the 2oth century. Two linked studies $\left(3^{8}\right.$, $46,48,49,99)$ described the development of partnerships between health and social services at the NHS primary care group or trust (PGG/T) level. They found that, despite the mandated local authority social services representation on PGG/T boards, general practitioners dominated decision making and social services representatives could be marginalised. Although relationships were improving over time, particularly among frontline staff, the studies concluded that considerable effort was still needed to build relationships and develop trust between agencies. Moreover, continuing organisational flux in the NHS had been likely to disrupt any established relations with social services departments.

Little empirical evidence was identified that demonstrated the oftenassumed benefits of agency-level partnership working, either for service delivery or in terms of outcomes for service users. Only one paper (93) sought to address whether integrated structures, such as NHS care trusts, associated with more integrated forms of service delivery. This compared old-age psychiatry services in England with those in Northern Ireland, where health and social services have been jointly administered since I973. They found that whilst the more integrated structures of Northern Ireland were associated with more integrated systems of service management, aspects of service delivery at the interface with the service user, such as referral and assessment practices, were no more likely to be integrated. Not one paper looked at the associated outcomes for older people.

Turning to the topic of joined-up services, the reviewed papers suggest that more progress had been made towards joined-up services in old-age 


\begin{tabular}{|c|c|c|c|c|c|}
\hline & Study & Themes & Design, methods & Subjects, units ${ }^{1}$ & Focus of study \\
\hline I & Abbey et al. I999 & IN & $\mathrm{S} ; \mathrm{SCQ}$ & $228 \mathrm{C}$ & Survey of visitors to residential homes to investigate quality of care. \\
\hline 2 & $\begin{array}{l}\text { Addington-Hall } \\
\text { et al. I } 99^{8}\end{array}$ & IN & $\mathrm{S} ; \mathrm{F}_{2} \mathrm{FQ}-\mathrm{S}$ & III SU & Interviews with carers of stroke patients who died at home or in a care home. \\
\hline 3 & Andrew et al. 2000 & IN & $\mathrm{Co} ; \mathrm{F}_{2} \widetilde{\mathrm{FQ}}-\mathrm{S} ; \mathrm{CA}$ & I4I SU & $\begin{array}{l}\text { Cohort study of people assessed by social services. Used multivariate analysis } \\
\text { to identify predictors of entry to long-term care. }\end{array}$ \\
\hline 4 & $\begin{array}{l}\text { Andrews, } \\
\text { Kendall } 2000\end{array}$ & IN & $\begin{array}{l}\mathrm{S} ; \mathrm{SCQ} ; \\
\mathrm{F}_{2} \mathrm{FQ}-\mathrm{SS}\end{array}$ & P: I I05, Q 150 & $\begin{array}{l}\text { Survey of former nurse proprietors of residential homes following the } \\
\text { introduction of the NHS and Community Care Act } 1990\end{array}$ \\
\hline 5 & $\begin{array}{l}\text { Andrews, } \\
\text { Phillips } 2000\end{array}$ & IN & $\begin{array}{l}\mathrm{S} ; \mathrm{SCQ} ; \\
\mathrm{F}_{2} \mathrm{FQ}-\mathrm{SS}\end{array}$ & P: I I05, Q I50 & Survey of proprietors in same study \\
\hline 6 & $\begin{array}{l}\text { Andrews, } \\
\text { Phillips } 2002\end{array}$ & $\mathrm{IN}$ & $\begin{array}{l}\mathrm{S} ; \mathrm{SCQ} ; \\
\mathrm{F}_{2} \mathrm{FQ}-\mathrm{SS}\end{array}$ & P: I I05, Q 150 & Longitudinal survey of proprietors in above study \\
\hline 7 & $\begin{array}{l}\text { Angunawela et al. } \\
2000\end{array}$ & IND & $\mathrm{OR} ; \widetilde{\mathrm{CR}}$ & $\mathrm{SU}$ I07 & $\begin{array}{l}\text { Before and after study comparing the discharge of dementia in-patients } \\
\text { from hospital before and after the introduction of the } \mathcal{N} H S \text { and Community } \\
\text { Care Act I99o }\end{array}$ \\
\hline 8 & Astin et al. 1995 & IN & Other ${ }^{2}$ & SU & $\begin{array}{l}\text { Modelling of GHS and census data to provide indicators of need for home } \\
\text { services in one county. }\end{array}$ \\
\hline 9 & Baillon et al. I996 & INT & S; SCQ & I32 P; $28 \mathrm{~T} / \mathrm{S}$ & $\begin{array}{l}\text { Questionnaire survey of professionals involved in caring for psychogeriatric } \\
\text { problems in residential homes. }\end{array}$ \\
\hline IO & $\begin{array}{l}\text { Bamford, Bruce } \\
2000\end{array}$ & IN & $\mathrm{S} ; \mathrm{F}_{2} \mathrm{FQ}-\mathrm{SS} ; \mathrm{FG}$ & I5 SU; $6 \mathrm{C}$ & $\begin{array}{l}\text { Explored the feasibility of consulting people with dementia about the types of } \\
\text { outcomes they seek from community care services. }\end{array}$ \\
\hline II & Banerjee I993 & IN & $\mathrm{S} ; \mathrm{F}_{2} \mathrm{FQ}-\mathrm{S} ; \mathrm{CA}$ & I69 SU & $\begin{array}{l}\text { Compared the prevalence of psychiatric disorders in one community care } \\
\text { service with recognition rates of these disorders by community care } \\
\text { professionals. }\end{array}$ \\
\hline I2 & $\begin{array}{l}\text { Banerjee, } \\
\text { Macdonald } 1996\end{array}$ & IN & $\mathrm{S} ; \mathrm{F}_{2} \mathrm{FQ}-\mathrm{S}$ & I69 SU & $\begin{array}{l}\text { Associations between mental disorder and health and social service use in a } \\
\text { home care population }\end{array}$ \\
\hline I3 & $\begin{array}{l}\text { Banerjee et al. } \\
\text { I996 }\end{array}$ & IN INT & RCT; CA & I69 SU & $\begin{array}{l}\text { Investigated the efficacy of intervention by a psychogeriatric team in the } \\
\text { treatment of depression in elderly disable people getting home care }\end{array}$ \\
\hline 14 & $\begin{array}{l}\text { Bannister et al. } \\
\text { I998 }\end{array}$ & IN & Co; CA & II $6 \mathrm{SU}$ & $\begin{array}{l}\text { Range of patient and carer variables as predictors of residential or nursing } \\
\text { home placement. }\end{array}$ \\
\hline I5 & $\begin{array}{l}\text { Bath, Morgan } \\
\text { I } 998\end{array}$ & IN & $\mathrm{Co} ; \mathrm{F}_{2} \mathrm{FQ}-\mathrm{S}$ & $\mathrm{IO}_{2} \mathrm{SU}$ & $\begin{array}{l}\text { Explored associations between physical activity and mortality and service use } \\
\text { over time. }\end{array}$ \\
\hline
\end{tabular}


Bedford et al. I996 INT IN

Bennett et al. $2000 \quad$ IN

Boniface

Denham 1997

Bowling et al. I993 IN

Bowling et al. I994 IN

Bowling et al. I995 IN

Brown et al. $2003 \quad$ INT IN

Brown et al. I996 INT IN

Burch et al. 1999

Burch et al. 2000

INT IND

INT IND

Burch, Borland

200I

Burholt $199^{8}$

Caldock I993

IN

IN

INT IND

IN
$\mathrm{Co} ; \mathrm{F}_{2} \mathrm{FQ}-\mathrm{S}$

${ }_{1042} \mathrm{SU}$

Co; OR; PE;

$\mathrm{F}_{2} \mathrm{FQ}-\mathrm{S}$; CA

$\mathrm{S} ; \mathrm{CR}$

$\mathrm{S} ; \mathrm{F}_{2} \mathrm{FQ}-\mathrm{S}$

$\mathrm{Co} ; \mathrm{F}_{2} \mathrm{FQ}-\mathrm{S} ; \mathrm{CA} \quad 640 \mathrm{SU}$

Co; CA

$640 \mathrm{SU}$

$\mathrm{Co} ; \mathrm{F}_{2} \mathrm{FQ}-\mathrm{S}$; CA 630 and $740 \mathrm{SU}$

\section{QE; F2FQ-SS; $\quad 393$ SU}

CA

$\mathrm{Co}$; OR; PE; CR I20 SU

\section{RCT; CA}

RCT; CA

I05 SU

I05 SU

\section{RGT(add on); $\quad$ I53 SU;} F2FQ-SS; CA Ior C; $9 \mathrm{P}$

$\mathrm{Co} ; \mathrm{F}_{2} \mathrm{FQ}-\mathrm{S} ; \mathrm{CR} \quad$ II7 $\mathrm{SU}$

$$
\mathrm{S} ; \mathrm{F}_{2} \mathrm{FQ}-\mathrm{SS} \quad \text { 40 P }
$$

S; SCQ; F2FQ-S; $308 \mathrm{SU}$ CR; CA
Explored the use of self-rated health as a predictor for future health and social service use.

Examined key processes and outcomes in joint health and social services community psychogeriatric teams

A pilot study to determine the appropriateness of nursing home placements in three inner-London boroughs post 1993 reforms.

Examined the relationships between use of community services and age, health status, social and economic factors, mental wellbeing and gender.

Explored the socio-demographic, social, psychological and physical characteristics of consistently high and consistently low users of services over time amongst the very elderly ( $>85 \mathrm{yrs}$ )

Assessed health and wellbeing, social and domestic circumstances and need for health and social services amongst very elderly people ( $>85 \mathrm{yrs}$ )

Examined whether increasing service use is associated with level of physical functioning, number and type of health problems, reported need for help, social networks

Evaluated whether an integrated (co-located) primary-care-based health and social care team is more clinically effective than a traditional non-integrated method of service delivery

Examined how community mental health teams for older people work by: identifying which patients pass through process and how contact pattern differs by diagnostic group; and by describing a typical caseload over i 8 months.

RCT comparing the outcome of day-hospital to day-centre rehabilitation.

RCT comparing day-hospital to day-centre rehabilitation using secondary outcome measures

Focused on the difficulties and opportunities encountered in the process of attempting to integrate health and social care provision in a day-care setting (alongside RCT)

Compared formal service visits and need for help with ADLs and household tasks of older people admitted to residential care with older people who stayed at home

Explored community care professionals' understandings about assessment arrangements and expectations, opinions and anxieties about anticipated I993 reforms

Investigated dependency and general health status of a cohort of older people admitted to care homes. 


\begin{tabular}{|c|c|c|c|c|c|}
\hline & Study & Themes & Design, methods & Subjects, units ${ }^{1}$ & Focus of study \\
\hline $3^{\mathrm{I}}$ & Challis et al. 2001 $a$ & IN & S; SCQ & $98 \mathrm{O}$ & $\begin{array}{l}\text { Explored whether typologies of care management arrangements for older } \\
\text { people could be discerned through the analysis of a series of key indicators. }\end{array}$ \\
\hline $3^{2}$ & Challis et al. 200I $b$ & IN IND & S; SCQ & Iог $\mathrm{O}$ & Examined how intensive care management at home had developed. \\
\hline 33 & Challis et al. $2002 a$ & INT IN & S; SCQ & $3^{\mathrm{I} 8 \mathrm{~T} / \mathrm{S}}$ & $\begin{array}{l}\text { Described and compared service arrangements in old-age psychiatry } \\
\text { across England }\end{array}$ \\
\hline 34 & Challis et al. $2002 b$ & IN IND & $\begin{array}{l}\text { QE; F F F-S; } \\
\text { CA; other (costs) }\end{array}$ & $86 \mathrm{SU}$ & $\begin{array}{l}\text { Quasi-experimental evaluation of a model of intensive case management } \\
\text { for people with dementia in a community-based mental health service for } \\
\text { older people. }\end{array}$ \\
\hline 35 & Challis et al. $2004 b$ & INT IN & $\begin{array}{l}\text { RGT; SCQ; } \\
\text { F2FQ-S }^{2}\end{array}$ & $256 \mathrm{SU}$ & $\begin{array}{l}\text { RCT evaluating the value of employing a specialist clinician's contribution } \\
\text { to the assessment of older people prior to care home entry. }\end{array}$ \\
\hline $3^{6}$ & $\begin{array}{l}\text { Chesterman et al. } \\
\text { 200I }\end{array}$ & IN & $\mathrm{Co} ; \mathrm{F}_{2} \mathrm{FQ}-\mathrm{S}$ & $4 \mathrm{I} 8 \mathrm{SU}$ & Investigated measures of user satisfaction with the care management process \\
\hline 37 & $\begin{array}{l}\text { Clarkson et al. } \\
2003\end{array}$ & IND & S; SCQ; FG & I6 O & $\begin{array}{l}\text { Investigated the potential effect of changing the residential allowance to } \\
\text { divert people away from residential care }\end{array}$ \\
\hline $3^{8}$ & $\begin{array}{l}\text { Coleman, } \\
\text { Rummery } 2003\end{array}$ & INT & $\begin{array}{l}\mathrm{S} ; \mathrm{CS} ; \mathrm{SCQ} ; \\
\mathrm{F}_{2} \mathrm{FQ}-\mathrm{SS} ; \mathrm{TI}-\mathrm{S} ;\end{array}$ & 72 and ${ }_{4} \mathrm{O}$ & $\begin{array}{l}\text { Examined the role and interpersonal relationships of the social services } \\
\text { representative on PCG/T boards. }\end{array}$ \\
\hline 39 & Cox 1997 & IN & $\mathrm{CS} ; \mathrm{F}_{2} \mathrm{FQ}-\mathrm{SS}$ & $5 \mathrm{O}$ & $\begin{array}{l}\text { Ways in which community care reforms and care management were being } \\
\text { implemented in the UK }\end{array}$ \\
\hline 40 & $\begin{array}{l}\text { Crawford et al. } \\
\text { I999 }\end{array}$ & IN & $\mathrm{S} ; \mathrm{CA}$ & $756 \mathrm{SU}$ & $\begin{array}{l}\text { Examined whether I } 993 \text { reforms resulted in better targeting of residential/ } \\
\text { nursing home care. }\end{array}$ \\
\hline $4^{I}$ & $\begin{array}{l}\text { Crawford et al. } \\
200 \mathrm{I}\end{array}$ & IN & $\mathrm{S} ; \mathrm{CA}$ & $389 \mathrm{SU}$ & $\begin{array}{l}\text { Consistency of dependency levels of people admitted to care homes in parts } \\
\text { of Northern Ireland }\end{array}$ \\
\hline $4^{2}$ & Darton et al. 2003 & IN & $\begin{array}{l}\text { S; SCQ; CA; } \\
\text { other (costs) }\end{array}$ & $\begin{array}{l}\text { I } 900 \mathrm{SU} \\
\text { 6I } 8 \mathrm{~T} / \mathrm{S}\end{array}$ & $\begin{array}{l}\text { Investigated the range of factors effecting costs of care in care homes } \\
\text { and the degree to which these factors changed over time. }\end{array}$ \\
\hline 43 & Dening et al. $\mathrm{I} 99^{8}$ & IN & $\mathrm{Co} ; \mathrm{F}_{2} \mathrm{FQ}-\mathrm{S} ; \mathrm{CA}$ & $2609 \mathrm{SU}$ & $\begin{array}{l}\text { Investigated the relationships between health/disability and service contact } \\
\text { over time. }\end{array}$ \\
\hline 44 & $\begin{array}{l}\text { Edwards, Jones } \\
\text { I998 }\end{array}$ & IND IN & $\mathrm{S} ; \mathrm{F}_{2} \mathrm{FQ}-\mathrm{S}$; CA & $\mathrm{I}_{4} \mathrm{O} 5 \mathrm{SU}$ & $\begin{array}{l}\text { Examined the ownership of assistive devices; determined their usage and } \\
\text { investigated the relationship between ownership and age, gender, living } \\
\text { arrangements and disability. }\end{array}$ \\
\hline 45 & Gabbay et al. 2003 & INT & $\begin{array}{l}\mathrm{PE} ; \mathrm{P} ; \mathrm{F}_{2} \mathrm{FQ}-\mathrm{SS} \\
\mathrm{OB} ; \mathrm{DOC}\end{array}$ & $2 \mathrm{O}$ & $\begin{array}{l}\text { Studied how 'communities of practice' work together; how consumers and } \\
\text { providers use knowledge in their collective decision-making }\end{array}$ \\
\hline
\end{tabular}



$2002 a$

Goodman et al. 2003

Hakim, Bakheit I $99^{8}$

Hallewell et al. I994

2003

Hardy et al. 1999

INI

IN

IND

IN

IN

Hughes et al. 200I

INT IN

Iliffe et al. I992

IN

$5^{8}$ Jacobs,

INT IND

Rummery 2002

Jacobs 2003

INT

$60 \quad$ Kirchner et al.

$$
2000
$$

6I Koffman et al. I996

$$
\begin{array}{ll}
\text { S; SCQ; TI-S } & 72 \mathrm{O} \\
\text { S; TI-S } & 570 \mathrm{~T} / \mathrm{S} \\
& \\
\text { S; CS; SCQ; } & 72 \text { and } 4 \mathrm{O} \\
\text { F2FQ-SS; TI-S } & \\
\text { S; PE; SCQ; } & \\
\text { F2FQ-SS; TI-S; } & \\
\text { DOC } & \\
\text { S; FG } &
\end{array}
$$

$\mathrm{S}$; other method

\section{Co; CR; CA}

$3^{8} \mathrm{SU}$

$\mathrm{QE} ; \mathrm{F}_{2} \mathrm{FQ}-\mathrm{S}$;

TI-S; CR; CA

$\mathrm{S} ; \mathrm{F}_{2} \mathrm{FQ}-\mathrm{S}$

I2 I SU

$87 \mathrm{SU} ; 57 \mathrm{C}$; $95 \mathrm{P}$

$\mathrm{S}$; F2FQ-SS; CR; $28 \mathrm{SU}$; $20 \mathrm{C}$; FG

$22 \mathrm{P}$

S; SCQ

IOI $\mathrm{O}$

$\mathrm{S} ; \mathrm{F}_{2} \mathrm{FQ}_{2} \mathrm{~S}$

239 SU

S; F2FQ-SS; TI-S 570 and $42 \mathrm{P}$

$\mathrm{S} ; \mathrm{F}_{2} \mathrm{FQ}-\mathrm{SS} ; \quad 50 \mathrm{P}$

TI-SS

$\mathrm{SL}$

Other ${ }^{3}$

I5IO SU
Explored progress made by PCG/Ts in developing partnerships with local authorities.

Investigated patterns of access to medical services for residents in homes for older people

Examined how health and social services are responding to and implementing policies for integrated services

Presented arguments re: macro and meso level constraints and barriers to

INT based on two empirical studies

Actual and potential contribution of primary-care nurses in residential homes for older people.

Investigated changes in risk of institutionalisation among older people over time

Examined the factors which influence length of hospitalisation of stroke patients

Explored what happened to frail older people when residential homes close and which factors affected outcome.

Measured and compared ratings of need for older people with mental health problems by the older person themselves, their carer and keyworker.

Explored the extent to which different types of choice had become a reality during care management assessment

Examined the relationship between care management and the care programme approach in the context of old-age mental health services.

Examined whether elderly people living alone are an at risk group with a

high level of morbidity that makes high demands on health and social services

A study of health service provision to older people in nursing homes to see whether nursing homes have the capacity to fulfil rehabilitation and intermediate care function

Investigated the perceptions and experiences of home managers and GPs of the provision of general medical services for older residents

Pilot study examining the costs of care in the community of people with dementia who had behavioural problems

Investigated the characteristics and appropriate placement of patients in specialist homes for the elderly mentally ill. 


\begin{tabular}{|c|c|c|c|c|c|}
\hline & Study & Themes & Design, methods & Subjects, units ${ }^{1}$ & Focus of study \\
\hline 62 & Lewis et al. 1994 & IND & OR; CR & $\mathrm{I} 475 \mathrm{SU}$ & $\begin{array}{l}\text { Compared the proportions of patients discharged to private care-homes or } \\
\text { elsewhere and lengths of time spent in hospital before and after the I993 } \\
\text { reforms }\end{array}$ \\
\hline 63 & $\begin{array}{l}\text { Lindesay et al. } \\
\text { I997 }\end{array}$ & IN & $\mathrm{S} ; \mathrm{F}_{2} \mathrm{FQ}-\mathrm{S} ; \mathrm{CA}$ & $297 \mathrm{SU}$ & $\begin{array}{l}\text { Investigated factors affecting the uptake of health and social services by } \\
\text { elderly Asian Gujarati }\end{array}$ \\
\hline 64 & $\begin{array}{l}\text { Livingston et al. } \\
\text { I } 997\end{array}$ & IN & $\begin{array}{l}\mathrm{S} ; \mathrm{F}_{2} \mathrm{FQ}-\mathrm{S} ; \mathrm{CA} ; \\
\text { methodı } \text { (costs) }\end{array}$ & $700 \mathrm{SU}$ & $\begin{array}{l}\text { Investigated the financial costs of formal community services for older people } \\
\text { with dementia, other mental health problems and physical disabilities }\end{array}$ \\
\hline 65 & $\begin{array}{l}\text { Livingston et al. } \\
2002\end{array}$ & IN & $\mathrm{S} ; \mathrm{F}_{2} \mathrm{FQ}-\mathrm{S} ; \mathrm{CA}$ & I085 SU & $\begin{array}{l}\text { Examined service utilisation of older immigrants compared to UK-born } \\
\text { counterparts }\end{array}$ \\
\hline 66 & Lloyd 2000 & INT IN IND & $\begin{array}{l}\text { S; CS; SCQ; } \\
\text { F}_{2} \text { FQ-SS }\end{array}$ & $\begin{array}{l}202 \text { and } 26 \mathrm{SU} \\
\mathrm{I} 40 \text { and } 26 \mathrm{C}\end{array}$ & $\begin{array}{l}\text { Assessments and service provision under the new community care } \\
\text { arrangements for people with Parkinson's disease and their carers (as an } \\
\text { exemplar of frail older people with complex needs). }\end{array}$ \\
\hline 67 & $\begin{array}{l}\text { MacDonald et al. } \\
\text { I996 }\end{array}$ & IN IND & $\mathrm{S} ; \mathrm{TI}-\mathrm{SS}$ & $326 \mathrm{C}$ & $\begin{array}{l}\text { Perceptions of carers of elderly long-stay care patients transferred to nursing- } \\
\text { homes in three health districts compared with those remaining in long-stay } \\
\text { geriatric NHS wards. }\end{array}$ \\
\hline 68 & $\begin{array}{l}\text { MacPherson et al. } \\
\text { I992 }\end{array}$ & IN & S; SCQ & $285 \mathrm{~T} / \mathrm{S}$ & $\begin{array}{l}\text { Survey of the extent and nature of the assessments used by private nursing- } \\
\text { homes. }\end{array}$ \\
\hline 69 & $\begin{array}{l}\text { Manthorpe, } \\
\text { Alaszewski } 2002\end{array}$ & IN INT & S; SCQ; TI-SS & $72 \mathrm{P}$ & $\begin{array}{l}\text { Services for people with dementia in a local authority and identified gaps in } \\
\text { service }\end{array}$ \\
\hline 70 & Martin et al. I999 & IN & S; SCQ & $40 \mathrm{O}$ & $\begin{array}{l}\text { Examined variations in the needs assessment policies and practices of social } \\
\text { services departments in England and Wales in dealing with elderly people } \\
\text { who have mental illness. }\end{array}$ \\
\hline $7 \mathrm{I}$ & McLeod 2003 & INT IND & $\mathrm{S} ; \mathrm{TI}-\mathrm{SS}$ & & $\begin{array}{l}\text { Investigated the degree to which A and } \mathrm{E} \text { based social workers enhanced health } \\
\text { and social care for older people from the older person's perspective. }\end{array}$ \\
\hline 72 & $\begin{array}{l}\text { McNamee et al. } \\
\text { I } 998\end{array}$ & INT IND & $\begin{array}{l}\text { RGT; F2FQ-S; } \\
\text { CR; CA; other } \\
\text { (costs) }\end{array}$ & $92 \mathrm{SU}$ & $\begin{array}{l}\text { Measured the net costs to the health and personal social services of an early } \\
\text { supported discharge policy for stroke. }\end{array}$ \\
\hline 73 & $\begin{array}{l}\text { McNamee et al. } \\
\text { I999 }\end{array}$ & IN & $\begin{array}{l}\text { S; F2FQ-S; CR; } \\
\text { CA; other (costs) }\end{array}$ & I055 SU & $\begin{array}{l}\text { Quantified service use and costs of supporting frail older people at home in } \\
\text { the community. }\end{array}$ \\
\hline 74 & Millard et al. 200I & IN & $\begin{array}{l}\text { S; other design } \\
\text { (modelling); SCQ }\end{array}$ & $6068 \mathrm{SU}$ & $\begin{array}{l}\text { Analysed a one-night bed occupancy census to determine whether it was } \\
\text { possible to model a total health and social care system for older people. }\end{array}$ \\
\hline
\end{tabular}


Parry-Jones,

Soulsby 200I

84 Penrice et al. 200I

Nelson et al. 2002

Netten 1992

Netten et al. 200I

Netten et al. 2003

Netten, Darton 2003

ewnham et al. I996

O'Dea et al. 2000

Philp et al. I995

Pollitt et al. I99I

Postle 2002

Proctor et al.

I999

Qureshi I999
IN

INT

IN

IN

IN

IN

\section{$\mathrm{S}$; F2 $\mathrm{FQ}_{2} \mathrm{~S}$; CA \\ ${ }_{1085} \mathrm{SU}$ \\ S; F2FQ-S; CA; $\quad{ }_{1085} \mathrm{SU}$ other (costs) \\ S; SCQ; F2FQ-S; $\quad \mathrm{IO}_{4} \mathrm{SU}$ \\ $\mathrm{OB} ; \mathrm{CA}$ \\ Co; F2FQ-S; CA $2438 \mathrm{SU}$}

S; SCQ; F2FQ- $\quad{ }_{25} \mathrm{P} ; 69 \mathrm{~T} / \mathrm{S}$;

SS; TI-SS 8I O

$\mathrm{S}$; F2FQ-S; CA 92I SU

$\mathrm{S}$; F2FQ-S; CR; $\quad$ ing SU

CA

S; TI-S

$\mathrm{S}$; F2FQ-SS

S; CR; CA

$\mathrm{S}$; F2 FQ-S; other $228 \mathrm{SU}$ (costs)

\section{$\mathrm{S}$; F2FQ-SS $\quad 34 \mathrm{C}$}

OBal; F2FQ-SS; $20 \mathrm{P}$

FG; OB

RCT; CA

I20 SU

$\mathrm{S} ; \mathrm{SCQ} ; \mathrm{F}_{2} \mathrm{FQ}$ $\mathrm{SS} ; \mathrm{FG}$

$89 \mathrm{P} ; 40 \mathrm{UG}$
Pattern and predictors of service use in representative sample of people aged $65+$ living at home.

Investigated the use, costs and factors associated with service usage amongst people aged 65 and over in inner London.

A study of the effect of the social environment of residential care on people with senile dementia

Use of nursing and residential home care in an older cohort: changes over time including mortality, location, dependency, and relationship between dependency and costs of care.

Investigated the rate of closure of nursing homes for older people, the types of homes closing and the reasons for closure.

Investigated the circumstances of self-funded admissions to care homes and compared them to publicly-funded admissions.

Admissions from the community or hospital to private nursing-homes, to assess care management in operation and determine whether admission criteria or access are influenced by funding.

Arrangements for provision of general practitioner, nursing advice, chiropody, physiotherapy and speech and language services to nursing homes and the charging policies for those services.

64 then $3_{0} \mathrm{P} \quad$ Investigated whether practitioners conducted needs-led assessments and any changes in practice post 1993 reforms.

Investigated why nursing-home care had been recommended for elderly people of low dependency and whether other forms of care may have been more appropriate.

Measured and compared perceived financial burden, use of services, and perceived unmet service need of supporters of matched samples of demented and non-demented people.

Explored the experiences of elderly spouse carers of dementia sufferers and how this influenced their attitudes to and use of outside assistance.

Investigated care managers' reactions to the changed nature of their work following the I99o NHS and Community Care Act.

RCT of the effectiveness of old-age psychiatry outreach team training on the quality of care in nursing and residential homes

Assessed different perspectives and attitudes towards collecting outcome information in social-care practice. 


\begin{tabular}{|c|c|c|c|c|c|}
\hline & Study & Themes & Design, methods & Subjects, units ${ }^{1}$ & Focus of study \\
\hline 90 & $\begin{array}{l}\text { Reed, Stanley } \\
2003\end{array}$ & IND IN & $\mathrm{P} ; \mathrm{F}_{2} \mathrm{FQ}-\mathrm{SS} ; \mathrm{FG}$ & I9 SU; $56 \mathrm{P}$ & $\begin{array}{l}\text { Developed and evaluated a daily living plan for older people discharged from } \\
\text { hospital to care homes }\end{array}$ \\
\hline $9^{\text {I }}$ & Reed et al. 2003 & IN & $\begin{array}{l}\mathrm{S} ; \mathrm{SCQ} ; \mathrm{F}_{2} \mathrm{FQ}- \\
\mathrm{SS} ; \mathrm{CR} ; \mathrm{FG}\end{array}$ & $\begin{array}{l}\text { I2 } \mathrm{SU} ; 3^{\circ} \mathrm{P} \\
84 \mathrm{~T} / \mathrm{S}\end{array}$ & Explored older people's experiences of relocations \\
\hline 92 & Reid et al. 200 I & IND IN & $\mathrm{S} ; \mathrm{F}_{2} \mathrm{FQ}-\mathrm{SS}$ & I9 SU & $\begin{array}{l}\text { Explored the question of unmet needs in relation to people with dementia } \\
\text { receiving respite services and considered their status as service users. }\end{array}$ \\
\hline 93 & Reilly et al. 2003 & INT IN & S; SCQ & 33I P & $\begin{array}{l}\text { Investigated whether integrated structures were associated with more } \\
\text { integrated forms of service delivery in old-age psychiatry }\end{array}$ \\
\hline 94 & Richards 2000 & IN & $\mathrm{OB} ; \mathrm{F}_{2} \mathrm{FQ}-\mathrm{SS}$ & $\begin{array}{l}25 \mathrm{SU} \text { and } \mathrm{C} \text {; } \\
\text { I7 P }\end{array}$ & $\begin{array}{l}\text { Investigated of the ways in which the needs of older people are negotiated } \\
\text { during the assessment process. An ethnographic approach. }\end{array}$ \\
\hline 95 & $\begin{array}{l}\text { Richardson et al. } \\
2000\end{array}$ & INT & RCT; other ${ }^{4}$ & $\mathrm{I} 2 \mathrm{O} \mathrm{SU}$ & $\begin{array}{l}\text { Explored the impact on costs associated with providing an old-age psychiatry } \\
\text { outreach team giving training and education for staff in nursing and } \\
\text { residential homes. Part of an RCT. }\end{array}$ \\
\hline 96 & $\begin{array}{l}\text { Robinson, } \\
\text { Drinkwater } 2000\end{array}$ & INT IN & PE; FG; other ${ }^{5}$ & II $\mathrm{SU} ;$ I $\mathrm{T} / \mathrm{S}$ & $\begin{array}{l}\text { Explored the process of care provided by a mutidisciplinary (inc. social work) } \\
\text { community-based geriatric assessment and management team using a } \\
\text { critical incident approach. }\end{array}$ \\
\hline 97 & Ross, Tissier 1997 & INT IN & $\begin{array}{l}\mathrm{PE} ; \mathrm{CS} ; \mathrm{F}_{2} \mathrm{FQ}- \\
\mathrm{SS} ; \mathrm{CR}\end{array}$ & 35I SU; I T/S & $\begin{array}{l}\text { Evaluation of the GP practice as a setting for assessment and care management; } \\
\text { the potential benefits of co-ordinating social work and district nurse } \\
\text { assessments of needs of older people. }\end{array}$ \\
\hline 98 & $\begin{array}{l}\text { Rothera et al. } \\
2003\end{array}$ & IN & Co; CR; CA & I888 SU & $\begin{array}{l}\text { Investigated dependency and health status of a cohort of older people admitted } \\
\text { for long-term nursing or residential care and compared these findings with } \\
\text { assessments conducted by social services departments prior to placement. }\end{array}$ \\
\hline 99 & $\begin{array}{l}\text { Rummery, } \\
\text { Coleman } 2003\end{array}$ & INT & $\begin{array}{l}\mathrm{S} ; \mathrm{CS} ; \mathrm{SCQ} ; \\
\text { F2FQ-SS; TI-S }\end{array}$ & 72 and ${ }_{4} \mathrm{O}$ & $\begin{array}{l}\text { Examined the development of partnership working between PCG/Ts and } \\
\text { social services departments for the delivery of services, particularly whether } \\
\text { integration into one organisation was a desirable or feasible goal. }\end{array}$ \\
\hline $\mathrm{IOO}$ & $\begin{array}{l}\text { Schneider et al. } \\
2002\end{array}$ & IN & $\mathrm{S} ; \mathrm{F}_{2} \mathrm{FQ}-\mathrm{S}$ & I32 SU & $\begin{array}{l}\text { Investigated what services people with dementia and their carers used; what } \\
\text { factors were associated with service receipt; what services informal carers } \\
\text { provided; and what was the effect of different living arrangements. }\end{array}$ \\
\hline IOI & $\begin{array}{l}\text { Schneider et al. } \\
2003\end{array}$ & IN & $\mathrm{Co} ; \mathrm{F}_{2} \mathrm{FQ}-\mathrm{S}$; CA; & I32 SU & $\begin{array}{l}\text { Explored the variations in informal and formal care costs according to the living } \\
\text { arrangements of people with dementia, by level of dependency and over time. }\end{array}$ \\
\hline IO2 & Shepherd ig96 & IND & $\begin{array}{l}\mathrm{S} ; \mathrm{F}_{2} \mathrm{FQ}-\mathrm{SS} \\
\mathrm{TI}-\mathrm{SS}\end{array}$ & гоо $\mathrm{SU} ; 36 \mathrm{C}$ & $\begin{array}{l}\text { Examined user and carer experiences of and views about arrangements for } \\
\text { hospital discharge and the community support provided afterwards. }\end{array}$ \\
\hline
\end{tabular}



2002

Trieman et al. I996

Io9 Victor et al. 2000

IND

IIo von Abendorff et al. 1994

II I Walker et al. I998

IN INT

IND IN

II4 Warnes et al. I997

II5 Weinberg et al. 2003

II6 Weiner et al. 2002

II7 Weiner et al. 2003
S; SCQ
4678 then
$6079 \mathrm{SU}$
S; DOC
$50 \mathrm{AF}$

S; SCQ

I540 SU

$$
\mathrm{CS} ; \mathrm{F}_{2} \mathrm{FQ}-\mathrm{SS} \quad \text { I2 } \mathrm{SU}
$$

S; FG

$$
\text { QE; CA }
$$

\section{S; CR}

S; diary

$456 \mathrm{SU}$

$\mathrm{S} ; \mathrm{F}_{2} \mathrm{FQ}-\mathrm{S}$; CA

I6 $\mathrm{P}$

$\mathrm{S}$; SCQ; F2FQ- I6I then 2II SS; TI-SS T/S; II O

S; F2FQ-SS; CR; 55 SU; 37 C; timeI $28 \mathrm{P}$

$\mathrm{S}$; other method

$67 \mathrm{PC}$ (mean

S; diary $34 \mathrm{P}$

S; SCQ

IOI $\mathrm{O}$

SCQ; TI-SS
Determined the changes between 1979 and I990 in demography and dependency levels in a repeated census of older people in residential care.

Analysed a nationally-representative sample of social services assessment

documents for older people for content and coverage.

Examined the socio-demographic and health determinants of the use of both statutory and private home-care services by older people living in the community.

Investigated the subjective meanings for older people of: needs experienced at the time of referral to social services; significance of decision of social services not to meet needs; implications of this decision on day-to-day lives; self perceived outcomes.

Examined and prioritised social-care needs for older people from three ethnic minority groups.

Examined the outcomes of older functionally mentally-ill patients who had left long-stay hospitals in comparison with a similar group who stayed there.

Examined the extent of the delayed discharge of older patients from acute

hospital wards and analysed the factors associated with such delays.

Examined the distribution of time use by different professional staff working in two community mental health teams for older people

Compared rates of mental health problems, disability and use of health and social services of older people in sheltered accommodation with age peers in rest of the community.

Investigated the development and changes in the local-authority funded market for home care between 1995 and I999.

Examined how community care was being arranged, delivered and received. Views of older people, carers and care managers. Follow up to Hardy et al., I999.

Investigated the characteristics of elderly populations associated with variations in their use of community health and personal social services.

Assessed the pattern of working practices of care managers working with older people.

Different care management arrangements for older people's services post-I993 reforms.

IOI then $18 \mathrm{O}$ Investigated the range and scope of the care management role undertaken by health-care professionals in the care of older people 
T A B L E 8. (cont.)

\begin{tabular}{|c|c|c|c|c|c|}
\hline & Study & Themes & Design, methods & Subjects, units ${ }^{1}$ & Focus of study \\
\hline II 8 & Wenger I999 & IN & $\mathrm{S} ; \mathrm{Co} ; \mathrm{F}_{2} \mathrm{FQ}-\mathrm{S}$ & 490 then $72 \mathrm{SU}$ & $\begin{array}{l}\text { Explored the impact of the implementation of the } 1990 \text { NHS and Community } \\
\text { Care Act in I } 993 \text { on service use and provision and considered views and } \\
\text { preferences of older people to paying for care and sources of care. }\end{array}$ \\
\hline II9 & Wills, Leff I996 & IND & $\mathrm{S} ; \mathrm{F}_{2} \mathrm{FQ}-\mathrm{S} ; \mathrm{OB}$ & IIо SU I; I74 O & $\begin{array}{l}\text { Compared the quality of life for psychogeriatric patients in a long-stay } \\
\text { psychiatric hospital with that in four community residences developed as part } \\
\text { of a reprovision programme for the hospital. }\end{array}$ \\
\hline $\mathrm{I} 2 \mathrm{O}$ & Wills et al. 1998 & IND & $\mathrm{S} ; \mathrm{F}_{2} \mathrm{FQ}-\mathrm{S}$ & I68 P & $\begin{array}{l}\text { Investigated whether community-based facilities were successful in establishing } \\
\text { a home-like environment for ex-hospital psychogeriatric patients and the } \\
\text { impact on quality of life. }\end{array}$ \\
\hline I2I & $\begin{array}{l}\text { Wittenberg et al. } \\
\text { 200I }\end{array}$ & IN & Other $^{6}$ & & $\begin{array}{l}\text { Made projections of likely demand for long-term care for older people under } \\
\text { different scenarios. }\end{array}$ \\
\hline $\mathrm{I} 22$ & $\begin{array}{l}\text { Wood, Castleden } \\
\text { I993 }\end{array}$ & IND IN & $\mathrm{S} ; \mathrm{F}_{2} \mathrm{FQ}-\mathrm{S} ; \mathrm{CA}$ & $497 \mathrm{SU} ; 20 \mathrm{~T} / \mathrm{S}$ & $\begin{array}{l}\text { Compared features of public and private sectors providing care for older } \\
\text { people. }\end{array}$ \\
\hline I23 & Wright I994 & IND IN & $\begin{array}{l}\mathrm{S} ; \mathrm{CS} ; \mathrm{SCQ} ; \\
\mathrm{F}_{2} \mathrm{FQ}-\mathrm{SS} ; \mathrm{OB}\end{array}$ & I05 then $6 \mathrm{~T} / \mathrm{S}$ & $\begin{array}{l}\text { Investigated the type and scope of services provided by multipurpose homes } \\
\text { and described the benefits and drawbacks of this model. }\end{array}$ \\
\hline I24 & Wright 2003 & IN & $\begin{array}{l}\text { S; CS; SCQ; } \\
\text { F2FQ-SS; TI-SS }\end{array}$ & $56 \mathrm{SU}$ & $\begin{array}{l}\text { To identify and explore the significant and controversial issues affecting the } \\
\text { key actors involved in older people paying the full cost of their long-term } \\
\text { residential or nursing-home care. }\end{array}$ \\
\hline
\end{tabular}

Key to themes: IN individuals' needs; IND independence; INT integration.

Key to design and methods: Co cohort; CA client assessed; CS case study; DOC document review; F2FQ-S structured face-to-face interviews; F2FQ-SS semi-structured face-to-face interviews; FG focus group; OB observation; OR outcome evaluation; P participatory; PE process evaluation; QE quasi-experimental; SCQ selfcompletion questionnaire; TI-S telephone interviews (structured); TI-SS telephone interviews (semi-structured).

Key to subjects or units of analysis: AF assessment forms; $\mathrm{C}$ carers; I interviews; O observations; P professionals; PC postcode sectors; $\mathrm{Q}$ questionnaires; RCT randomised-controlled trial; $\mathrm{SU}$ service users; T/S team/service; UG user groups.

Other notes: I. Papers scoring ' 5 ' or above out of a possible ' 7 ' on different aspects of quality. 2. Other design (modelling); other method (secondary analysis). 3 . Other design (cost analysis); diary; other method (costs). 4. Other design (economic evaluation); other method (costs). 5. Other method (critical incident technique).

6. Other design (modelling); other method. 
mental health services than in mainstream older people's services, possibly following the lead of old-age psychiatry. The evidence for integrated working in old-age mental health services was strongest for liaison and training (33). In particular, there were many close links with care homes, which had better access to and relationships with psychogeriatric services than with other specialist health services $(9,58)$. There was less evidence, however, of formal integration through, for example, shared management of staff. In 2000, only 59 per cent of old-age psychiatry teams had socialcare staff as members (33).

Some papers documented the benefits of social worker placement in general practitioners' (GP) surgeries, both for users and their carers (ease of access) (23) and for the staff involved (closer inter-professional working) (97). Integrated systems of care management, however, by which healthcare staff assume responsibility for co-ordinating care packages, as suggested in the early guidance (Social Services Inspectorate and Social Work Services Group (SSI/SWSG) I99 $a$, I99 I $b$ ), were slower to develop and difficult to maintain. A national survey of local authorities in I997/8 demonstrated that only 2 I out of Ior respondents had NHS staff acting as care managers for older people (3I). A follow-up study in 200 I found that this was still the case in only I4 of these authorities (II7). Moreover, the effectiveness of this and other existing models of integrated care-delivery in the UK remains to be evaluated.

This review revealed little evidence of the development of a generic health and social-care worker for older people. Whilst earlier studies had demonstrated the role's potential (e.g. Challis et al. I99 I $a$, I99i $b$ ), only one paper meeting the inclusion criteria for the current review (but not the median quality score) explicitly evaluated the development - it was a small process evaluation that demonstrated equivocal success (Taylor 200I). Indeed, despite the widely held presumption that integrated services are favourable for older people, evidence of their benefits was generally lacking, as other reviews have found (Dowling, Powell and Glendinning 2004). There is, however, clear evidence of the barriers to integrated health and social care among the reviewed paper $(23,97)$ and elsewhere (Johnson et al. 2003). They include professional mistrust, threats to professional identities, and problems with information sharing.

\section{Independence}

Studies of hospital discharges of older people from long-stay hospital wards were not well represented during the review period - in contrast to the Ig8os, when discharge from acute hospital care, in particular delayed hospital discharge, was a prominent theme. The reported incidence of 
delayed discharge in studies identified for the current review averaged around 25 per cent of admissions (6r, I09). The identified reasons for delayed discharge were delays in: care-home placement $\left(7,5^{2}, 61\right.$, Iog), the assessment process (7, I09), and the completion of care packages including necessary home adaptations and equipment (52), and the absence or breakdown of carer arrangements (7, I09). Other factors such as access to rehabilitation in hospital, dependency and age were not found to be significant causes. In other words, organisational issues, including many involving co-ordination with social services, were identified as the main cause of delayed discharges.

Moving on to rehabilitation, few peer-reviewed publications were found on the contribution of social services to rehabilitation in older people's services, and those identified did not rate highly on the seven quality criteria. For example, one study which sought to identify the different models of community rehabilitation in the UK and that collected data on the structure of 98 different teams failed to examine explicitly the involvement of social-care staff (Enderby 2002). Another study of community rehabilitation that did investigate aspects of integration with social care compared only six teams (Geddes and Chamberlain 200I). Variations in team structure and the services offered were assumed to relate directly to the particular purpose of each team, and a taxonomy of four types of rehabilitation service was proposed. It is hard to draw any conclusions relating to social care from such a small sample, however, and no identified studies investigated the relative benefit of integrated teams for older service users. One of the few identified RGTs was high quality and compared day-hospital rehabilitation to rehabilitation by health staff in a social-services day centre $(25,26,27)$. Whilst the outcomes were similar for older people and their carers in each setting, the day-centre model was less popular.

The focus on rehabilitation in older people's services has been largely subsumed by the intermediate care agenda in the UK (Cm 4818-I 2000), but peer-reviewed evaluations of intermediate care services that explicitly involved social services were scarce: only three papers were identified in the current review and only two scored ' 5 ' or above on quality. One of these was an RCT of an integrated supported early-discharge team for stroke patients (72). Despite the small sample size, this study suggested that the intervention was a cost-effective alternative to hospital care in the management of stroke. The remaining paper which could inform developments in intermediate care was descriptive and examined access to health care for older residents of care homes taking a mixed-methods approach. It found that whilst access to therapy services was possible for most homes, it was often difficult and had to be paid for privately, with 
potentially some negative consequences for the sector's capacity to provide intermediate care services $\left(5^{8}\right)$.

\section{Care at home or in homelike environments}

In relation to this area of enquiry, two services covered by the research literature will be considered here: day-care services and intensive care management for older people. Day-care services offer both social and respite care and facilitate interactions between older people. Several benefits of day care were suggested in the reviewed papers but they had below the median quality scores: social interaction, improvements in mood and behaviour of dementia sufferers, improved social functioning and avoidance of admission to residential care (Curran i996; Powell 200o). No rigorous evaluations of the impact of day care were identified, but included papers did suggest that day services were changing. For example, new developments, such as integrated day-centre rehabilitation and day-care provision in multi-purpose care homes were evaluated but demonstrated variable success $(25,26,27)$. An intensive-care management demonstration study (34) met the inclusion criteria and indicated the capacity of this approach not only to provide an alternative to care-home admission but also to improve wellbeing and support to carers. By I997/8, however, only five per cent of English local authorities provided such a service (32), despite no evidence of the cost effectiveness of less targeted forms of care management (discussed further below).

\section{Direct payments}

Given the reference period of the current review (I990-200I), it is unsurprising that little empirical evidence was identified concerning the use of direct payments by older people. Just one small study in a peer-reviewed journal was identified (Leece 200I), for which only three older users of direct payments were interviewed.

\section{Making sure services fit individuals' needs}

\section{Assessment and care management}

The general anxiety felt by community-care professionals prior to the introduction of the 'new' process of assessment for care management was highlighted in a I993 paper, the year of full implementation of the community care reforms (29). This qualitative study identified three issues of concern that later became recurrent themes in the literature: the conflicting role of the assessor; the identification of unmet needs; and, 
in particular, difficulties in conducting a needs-led assessment. Most papers in this review that examined the assessment process were concerned with the success or failure of a needs-led approach to assessment. In this respect, studies provided evidence of the way in which social workers' concepts of needs were inextricably linked to services and eligibility criteria (83); that with ever-tightening budgets, assessments were becoming even more resource-led (83); that user choice in the assessment process was restricted (55, I13); and that despite older people's reluctance to enter care homes, they often acquiesced to professional recommendations (9I). There was also debate about the desirability of structured assessments. A nationally-representative survey of 50 assessment documents, whilst highlighting wide variations in the domains covered by these instruments, found that most were structured, some highly so (IO4). Whilst promoting consistency in the assessment process and aiding the generation of aggregate data, structured assessment forms were also criticised for their inflexibility (Ellis, Davis and Rummery 1999), and incompatibility with users' perceptions of need (Rummery, Ellis and Davis 1999). These papers did not provide a full account of their methodology and did not reach the median quality score.

Despite the provision of guidance on care management (SSI/SWSG I991 $a$, I99I $b$ ), this review found marked variation in the ways in which care management developed following the $\mathcal{N H S}$ and Community Care Act I99o (32, I 6, II $)$. In particular, as reported earlier, very few local authorities employed NHS staff as care managers, indicative of more integrated forms of care co-ordination, and even fewer operated intensive-care management schemes for older people. Budgetary devolution to care managers was rare (39), and systems for the monitoring and review of care packages poorly developed (55, II3). Many of these aspects of care management were vital to the success of the original demonstration studies (Challis I993) that targeted the most highly dependent older people at high risk of care-home admission. Instead, the identified papers suggested that care management had become a process applied to all older people referred to social services departments, irrespective of need. Moreover, there was no evidence of the relative cost-effectiveness of different models of care management for older people.

\section{Service commissioning}

Included papers provided useful information for service commissioning in terms of measuring service use, unmet needs and costs; issues affecting social-care markets; methods for measuring outcomes; and user involvement in commissioning processes, but few looked at the commissioning 
process itself in detail. Several studies aimed to identify the predictors of domiciliary and day-care use and care-home admissions. The most commonly identified predictors of home care, and those most strongly associated with service use, were dementia $(64,73,76$, I0o), living alone (or the absence of a cohabitant or family carer) (I9, 5I, 64, 73, 76, Iоo, II4), physical dependency (or activity limitation) (I2, I9, 21, 22, 64, 73, 76) and age (I9, 43, 44, 51, 64). Living alone (19, 57, 65, 75) and dementia (19, 65, 75, 85) were also the most commonly reported predictors of using day-care services. Of particular interest to policy-makers and planners aiming to divert older people away from institutional care were studies that identified factors associated with care-home admission. Again, dementia (and its severity) was identified as one of the strongest predictors of admission (3, I4, I7, 78), but also influential was whether there was a family carer, her or his ability to cope and their level or stress $(3, \mathrm{I} 4, \mathrm{I} 7,5 \mathrm{I}, 78)$. This is a clear indication of the potential of carer-support services to help maintain older people for longer in their own homes. Interestingly, a national study of care-home admissions (78) concluded that characteristics of the individual explained over 80 per cent of admissions, and that supply factors, although significant, added nothing to the power of the statistical model developed. One surmises, therefore, that up to 20 per cent of admissions may be explained by service-related factors, which are open to modification by service planners.

\section{Preventative services}

Only two papers that explicitly investigated the provision of low-level preventative services met the inclusion criteria. Both qualitative studies, they provided evidence of the value placed on such services by older people. One suggested that help with housework was instrumental in allowing older women in particular to remain in their own homes (Clark and Dyer i998), but provided insufficient detail of the methodology to allow a full judgement of quality. The other described difficulties faced by older people in asking for help from others when statutory services were unavailable (ı06).

\section{Targeting assistance}

Most publications on targeting concerned the appropriateness of carehome placements. It has been estimated that almost one-third of those admitted are inappropriately placed or have a low level of dependency $(\mathrm{I} 8,30,81,84$, I24). Variation in placement decisions between different areas was demonstrated for both England (78) and Northern Ireland (4I). 
These authors suggest this is likely to be due to the availability and success of alternative services aimed at maintaining people at home for longer.

\section{Discussion}

This review has uniquely taken a systematic approach to the identification, critical appraisal and synthesised evaluation of the peer-reviewed research literature pertaining to social care for older people. By doing so, it has provided not only a picture of the state of these services in the United Kingdom at the end of the 2oth century but also identified where further investment in research is required to improve the evidence base. The review has demonstrated where the research evidence is strong (Table 7) and may have helped inform policy change. For example, in relation to delayed hospital discharge, the evidence strongly suggests that the main causes relate to organisational issues, particularly at the interface of hospital and community. The Community Care (Delayed Discharges etc.) Act 2003 subsequently placed new duties and responsibilities on both social services authorities and the NHS, thereby recognising the joint responsibility for ensuring timely discharges $(\mathrm{DH} 2003 b)$. Whilst this may represent 'evidence-based policy' in action, it could also be argued that other drivers for change were as important, such as financial and political pressures to eliminate problems of 'bed-blocking'.

The review has also identified weaknesses in the evidence base, both in terms of gaps (Table 7) and in respect of the quality of published studies (Tables 4 and 5); in these areas, policy and practice appears to have advanced without research evidence. For example, in the case of intermediate care services, the dearth of peer-reviewed publications is surprising. Even within the health-care sector where there is a stronger tradition of evidence-based policy and practice, developments in intermediate care have been viewed as lacking an evidence base (Vetter 2005). Although the national ex post evaluation of intermediate care has now reported (Intermediate Care National Evaluation Team 2006), questions remain over the relative cost effectiveness of the different forms, functions and processes of intermediate care (of which there are many), and for different types of service user.

This review suggests that there is a general need for higher quality and fuller methodological reporting of studies of the social care for older people. If evidence-based practice and policy is to become a reality in social care for older people, it requires a solid foundation of scientific research, rigorously designed, executed and disseminated, and that addresses an appropriate range of research questions. High-quality research 
is required on the structure and process, as well as outcomes of services, reflecting the nature of the subject being investigated and its state of development. We need to know not just what to provide, but how to provide it in such a way that will maximise the benefits for older people. More investment is required in research to determine the effectiveness and costeffectiveness of: modes of service integration for different groups of older service users, how best to confer the same degree of choice, control and independence afforded to some younger disabled adults through direct payments, and how to commission and organise services around the needs of the individual older person. For the studies to be useful to policy makers, service commissioners and practitioners, they must deliver on the different dimensions of methodological quality assessed in this review, for only then will they constitute a sound evidence base.

The systematic review has also provided baseline information from which to judge the impact of the modernisation of social care for older people. Public-services reform is a continuous process in the UK. With roots in the neo-liberal reforms of the Ig8os and I9gos, it continued through a 'radical programme' of reform during the Labour party's third subsequent administration (Blair 2005). For older people's services, the standards set out in the NSFOP continue to be reflected in the 2006 White Paper for community services, Our Health, Our Care, Our Say (Cm 6737 2006), whilst new initiatives are in train to promote the integration of health and social care, independence and person-centred care (DH $2007 b$ ), underpinned by the 'choice' agenda that is applied to many public services. Modernising social care for older people is no small task. Socialcare spending runs at $\mathrm{f}_{\mathrm{i}} 3.8$ billion in adult services - older people being the single largest user group and accounting for 44 per cent (Health and Social Care Information Centre 2006). Moreover, increasing financial pressures are inherent in many of the recent modernisation reforms that seek to divert further the care of older people from acute hospitals to the community, e.g. intermediate care and the new health and social care model for managing long-term conditions ( $\mathrm{DH}$ 2005). Without an adequate evidence base, however, policy makers and commissioners will struggle to ensure that service improvements can be made with finite resources.

\section{Acknowledgements}

This study was funded by the UK Department of Health Policy Research Programme. We are grateful to Helen McEvoy and Mary Ingram who helped with the initial searches for literature and with setting up databases to manage the 
review process. We also thank Ross Millar who helped with the retrieval of articles. The views expressed are those of the authors alone.

\section{NOTES}

I Cm and Cmnd (formerly used) abbreviate Command. United Kingdom government publications presented to Parliament are known as Command Papers. Most but not all Command Papers are published in a numbered series. They include White Papers, government policy initiatives and proposals for legislation, and Green Papers, government consultation documents (see http://www.parliament.uk/about/how/ publications/government.cfm).

2 The electronic databases searched were: Cambridge Scientific Abstracts (CSA) hosting Applied Social Sciences and Abstracts (ASSIA), Sociological Abstracts and Social Services Abstracts; CareData (produced by the UK National Institute for Social Work); Cumulative Index to Nursing and Allied Health Literature (Cinahl); The Cochrane Library; Health Management Information Consortium (HMIC); Medline; PsycInfo (produced by the American Psychological Association) and the Social Science Citation Index (SSCI).

3 The hand-searched journals were: British fournal of Social Work, Health and Social Care in the Community, Fournal of Social Policy, Fournal of Social Work, Social Policy and Administration, Journal of Interprofessional Care, Age and Ageing, Ageing \& Society, International Fournal of Geriatric Psychiatry, and Quality in Ageing.

4 The bibliographic software package, Reference Manager vio was used to organise the references (ISI ResearchSoft 200i).

5 Cronbach's alpha is based on the average correlation between each of the seven items, indicating the extent to which all of the items measure the same dimension (Cronbach 195I).

\section{References}

\section{Note: An asterisk (*) indicates that the paper was included in the systematic review.}

*Abbey, A., Schneider, J. and Mozley, C. I999. Visitors' views on residential homes. British Journal of Social Work, 29, 4, 567-79.

*Addington-Hall, J., Lay, M., Altmann, D. and McCarthy, M. I998. Community care for stroke patients in the last year of life: results of a national retrospective survey of surviving family, friends and officials. Health and Social Care in the Community, 6, 2, 112-9.

Anderson, G. F. and Hussey, P. S. 200o. Population aging: a comparison among industrialized countries. Health Affairs, 1 9, 3, I9I-203.

*Andrew, T., Moriarty, J., Levin, E. and Webb, S. 200o. Outcome of referral to social services departments for people with cognitive impairment. International fournal of Geriatric Psychiatry, I5, 5, 406-I4.

*Andrews, G. J. and Kendall, S. A. 2000. Dreams that lie in tatters: the changing fortunes of nurses who left the British NHS to own and run residential homes for elderly people. Fournal of Advanced Nursing, 31, 4, 900-8.

*Andrews, G. J. and Phillips, D. R. 2000. Private residential care for older persons: local impacts of care in the community reforms in England and Wales. Social Policy and Administration, 34, 2, 206-222. 
*Andrews, G. J. and Phillips, D. R. 2002. Changing local geographies of private residential care for older people I983-I999: lessons for social policy in England and Wales. Social Science and Medicine, 55, I, 63-78.

*Angunawela, I., Barker, A. and Nicholson, S. D. 2000. The NHS and Community Care Act I990: impact on the discharge profile of patients with dementia. Psychiatric Bulletin, 24, 5, I $77-8$.

*Astin, M., Corden, A. and Slack, R. I995. Estimating the need for care at home: a tool for local authorities? Research, Policy and Planning, I3, I/2, 25-8.

Audit Commission 2000. Charging with Care: How Councils Charge for Home Care. Audit Commission, London.

Australia Department of Community Services and Health i99I. Aged Care Reform Strategy: Mid-Term Review, I990-9I Report. Australian Government Publishing Service, Canberra.

*Baillon, S., Neville, P. and Broome, C. I996. A survey of the relationship between community mental health teams and residential homes for the elderly. International Fournal of Geriatric Psychiatry, I I, 9, 807-I I.

*Bamford, C. H. and Bruce, E. 200o. Defining the outcomes of community care: the perspectives of older people with dementia and their carers. Ageing \& Society, 2o, 5, $543-70$.

*Banerjee, S. I993. Prevalence and recognition rates of psychiatric disorder in the elderly: clients of a community care service. International Fournal of Geriatric Psychiatry, 8, 2, I25-3I.

*Banerjee, S. and Macdonald, A. J. I996. Mental disorder in an elderly home-care population: associations with health and social service use. British fournal of Psychiatry, I68, 6, $75^{0}-6$.

*Banerjee, S., Shamash, K., Macdonald, A. J. and Mann, A. H. i996. Randomised controlled trial of effect of intervention by psychogeriatric team on depression in frail elderly people at home. British Medical Fournal, 3 I 3, 7064, I058-6I.

*Bannister, C., Ballard, C., Lana, M., Fairbairn, A. and Wilcock, G. I998. Placement of dementia sufferers in residential and nursing-home care. Age and Ageing, 27, 2, 189-93.

*Bath, P. A. and Morgan, K. I998. Customary physical activity and physical health outcomes in later life. Age and Ageing, 27, supplement 3, 29-34.

*Bath, P. A. I999. Self-rated health as a risk factor for prescribed drug use and future health and social service use in older people. Fournals of Gerontology: Medical Sciences, $\mathbf{5 4} \mathbf{A}$, II, $\mathrm{M}_{5} 65-70$.

*Bedford, S., Melzer, D., Dening, T., Lawton, G., Todd, C., Badger, G. and Brayne, G. I996. What becomes of people with dementia referred to community psychogeriatric teams? International Fournal of Geriatric Psychiatry, I I, 2, IO5I-6.

*Bennett, M., Smith, E., Victor, C. R. and Millard, P. H. 200o. The right person? The right place? The right time? A pilot study of the appropriateness of nursing-home placements. Archives of Gerontology and Geriatrics, 31, I, 55-64.

Blair, T. 2005. Prime Minister's Speech on Returning to Io Downing Street on 6 May 2005. Prime Minister's Office, London. Available online at http://www.number-Io.gov.uk/output/ Page 7459.asp [Accessed 24 November 2005].

*Boniface, D. R. and Denham, M. J. I997. Factors influencing the use of community health and social services by those aged 65 and over. Health and Social Care in the Community, 5, I, 48-54.

Boruch, R. F. 1997. Randomized Experiments for Planning and Evaluation: A Practical Guide. Sage, Thousand Oaks, California.

Bowling, A., Farquhar, M. and Grundy, E. I993. Who are the consistently high users of health and social services? A follow-up study two-and-a-half years later of people aged $85+$ at baseline. Health and Social Care in the Community, $\mathbf{1}, 5,277-87$. 
*Bowling, A., Farquhar, M. and Grundy, E. I994. Associations with changes in level of functional ability: results from a follow-up survey at two-and-a-half years of people aged 85 years and over at baseline interview. Ageing $\mathcal{E}^{2}$ Society, I 4, I, 53-73.

*Bowling, A., Farquhar, M. and Grundy, E. I995. Changes in health and social service use among three samples of older people in inner London. International Fournal of Health Sciences, 6, I, I-I3.

*Brown, L., Tucker, C. and Domokos, T. 2003. Evaluating the impact of integrated health and social care teams on older people living in the community. Health and Social Care in the Community, I I , 2, 85-94.

*Brown, P., Challis, D. and von Abendorff, R. I996. The work of a community mental health team for the elderly: referrals, caseloads, contact history and outcomes. International Fournal of Geriatric Psychiatry, I I, I, 29-39.

*Burch, S. and Borland, C. 20or. Collaboration, facilities and communities in day care services for older people. Health and Social Care in the Community, 9, I, I9-30.

*Burch, S., Longbottom, J., McKay, M., Borland, C. and Prevost, T. I999. A randomized controlled trial of day hospital and day centre therapy. Clinical Rehabilitation, 13, 2, IO5-I2.

*Burch, S., Longbottom, J., McKay, M., Borland, C. and Prevost, T. 200o. The Huntingdon Day Hospital Trial: secondary outcome measures. Clinical Rehabilitation, I4, 4, 447-53.

Burholt, V. 1998. Pathways into residential care: service use, help and health prior to admission. Health Care in Later Life, 3, I, I5-33.

*Caldock, K. I993. A preliminary study of changes in assessment: examining the relationship between recent policy and practitioners' knowledge, opinions and practice. Health and Social Care in the Community, I, 3, I39-46.

Challis, D. I993. Case management in social and health care: lessons from a United Kingdom programme. Journal of Case Management, 2, 3, 79-9o.

Challis, D., Darton, R., Johnson, L., Stone, M. and Traske, K. I99 $a$. An evaluation of an alternative to long-stay care for frail elderly patients: I. The model of care. Age and Ageing, 2o, $4,236-44$.

Challis, D., Darton, R., Johnson, L., Stone, M. and Traske, K. I99I $b$. An evaluation of an alternative to long-stay care for frail elderly patients: II. Costs and effectiveness. Age and Ageing, 20, 4, 245-54.

*Challis, D., Godlove Mozley, C., Sutcliffe, C., Bagley, H., Price, L., Burns, A., Huxley, P. and Cordingley, L. 2000. Dependency in older people recently admitted to care homes. Age and Ageing, 29, 3, 255-60.

*Challis, D., Weiner, K., Darton, R., Hughes, J. and Stewart, K. 200 I $a$. Emerging patterns of care management: arrangements for older people in England. Social Policy and Administration, 35, 6, 672-87.

*Challis, D., Darton, R., Hughes, J., Stewart, K. and Weiner, K. 200 $b$. Intensive caremanagement at home: an alternative to institutional care? Age and Ageing, 3o, 5, 409-13.

*Challis, D., Reilly, S., Hughes, J., Burns, A., Gilchrist, H. and Wilson, K. $2002 a$. Policy, organisation and practise of specialist old-age psychiatry in England. International fournal of Geriatric Psychiatry, I 7, I , IOI8-26.

*Challis, D., von Abendorff, R., Brown, P., Chesterman, J. and Hughes, J. $2002 b$. Care management, dementia care and specialist mental health services: an evaluation. International Fournal of Geriatric Psychiatry, I 7, 4, 315-25.

Challis, D., Xie, C.-Q., Hughes, J., Jacobs, S., Reilly, S. and Stewart, K. 2004a. Social Care Services at the Beginning of the 2Ist Century: Findings. Discussion Paper Mog8, Personal Social Services Research Unit, University of Manchester, Manchester.

*Challis, D., Clarkson, P., Williamson, J., Hughes, J., Venables, D., Burns, A. and Weinberg, A. 2004 $b$. The value of specialist clinical assessment of older people prior to entry to care homes. Age and Ageing, 33, I, 25-34. 
*Chesterman, J., Bauld, L. and Judge, K. 20or. Satisfaction with the care-managed support of older people: an empirical analysis. Health and Social Care in the Community, 9, I, 3I-42.

*Clark, H. and Dyer, S. I998. The Plimsoll line. Issues in Social Work Education, I 8, 2, 64-9.

*Clarkson, P., Hughes, J. and Challis, D. 2003. Public funding for residential and nursing home care: projection of the potential impact of proposals to change the residential allowance in services for older people. International Fournal of Geriatric Psychiatry, 18, 3, 2II-6.

Cm 849 i989. Caring for People. Her Majesty's Stationery Office (HMSO), London.

Cm I599 I991. The Citizen's Charter: Raising the Standard. HMSO, London.

Cm 3807 i997. The New NHS: Modern - Dependable. Stationery Office, London.

Cm 4i69 1998. Modernising Social Services. Stationery Office, London.

Cm 4310 I999. Modernising Government. Stationery Office, London.

Cm 4818-I 2000. The NHS Plan. A Plan for Investment. A Plan for Reform. Stationery Office, London.

Cm 6499 2005. Independence, Well-being and Choice. Stationery Office, London.

Cm 6737 2006. Our Health, Our Care, Our Say. Stationery Office, London.

Cmnd 4683 1971. Better Services for the Mentally Handicapped. HMSO, London.

Cmnd 6233 1975. Better Services for the Mentally Ill. HMSO, London.

Cmnd 8173 i98i. Growing Older. HMSO, London.

*Coleman, A. and Rummery, K. 2003. Social services representation in primary care groups and trusts. Fournal of Interprofessional Care, I 7, 3, 273-280.

Cowell, R. and Martin, S. 2003. The joy of joining up: modes of integrating the local government modernisation agenda. Environment and Planning C: Government and Policy, 2 I, 2, I59-79.

*Cox, C. I997. Case management: an American's observations of community care in Britain. Fournal of Case Management, 6, 3, 88-95.

*Crawford, V. L. S., Beringer, T. R. O. and Stout, R. W. I999. Comparison of residential and nursing-home care before and after the 1993 community-care policy. British Medical Journal, 318, 366 .

*Crawford, V. L. S., Beringer, T. R. O. and Stout, R. W. 200r. Common guidelines and equitable service: variation between adjacent districts regarding admissions to elderly care institutions. Aging: Clinical and Experimental Research, I3, 6, 414-20.

Cronbach, L. J. I95I. Coefficent alpha and the internal structure of tests. Psychometrika, I6, 297-334.

*Curran, J. S. M. I996. The impact of day care on people with dementia. International Fournal of Geriatric Psychiatry, $\mathbf{1}, 9,813-7$.

Daatland, S. O. 200I. Ageing, families and welfare systems: comparative perspectives. Zeitschrift für Gerontologie und Geriatrie, 34, I, I6-20.

*Darton, R., Netten, A. and Forder, J. 2003. The cost implications of the changing population and characteristics of care homes. International Fournal of Geriatric Psychiatry, $\mathbf{1 8}$, $236-43$.

*Dening, T., Chi, L. Y., Brayne, C., Huppert, F. A., Paykel, E. S. and O‘Connor, D. W. 1998. Changes in self-rated health, disability and contact with services in a very elderly cohort: a 6-year follow-up study. Age and Ageing, 27, I, 23-33.

Department of Health (DH) i999. Caring about Carers. A National Strategy for Carers. Local Authority Social Services Letters (LASSL) 992. Department of Health, London.

Department of Health 2000. A Quality Strategy for Social Care. DH, London.

Department of Health 200i. National Service Framework for Older People. DH, London.

Department of Health 2002. Guidance on the Single Assessment Process for Older People. Report

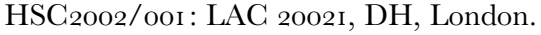

Department of Health 2003a. Direct Payments Guidance Community Care, Services for Carers and Children's Services, Direct Payments Guidance England. DH, London. 
Department of Health 2003 b. The Community Care (Delayed Discharges etc.) Act 2003: Guidance for Implementation. HSC 2003/oog: LAC 200321, DH, London.

Department of Health 2005. Supporting People with Long Term Conditions: An NHS and Social Care Model to Support Local Innovation and Integration. DH, London.

Department of Health 2007a. Modernising Adult Social Care: What's Working. DH, London. Available online at http://www.dh.gov.uk/en/Publicationsandstatistics/Publications/ PublicationsPolicyAndGuidance/DH_076203 [Accessed I8 April 2008].

Department of Health 2007 b. Putting People First: A Shared Vision and Commitment to the Transformation of Adult Social Care. HM Government, London. Available online at http:// www.dh.gov.uk/en/Publicationsandstatistics/Publications/

PublicationsPolicyAndGuidance/DH_o8ıir8 [Accessed 20 December 2007].

Dowling, B., Powell, M. and Glendinning, C. 2004. Conceptualising successful partnerships. Health and Social Care in the Community, I 2, 4, 309-17.

*Edwards, N. I. and Jones, D. A. I998. Ownership and use of assistive devices amongst older people in the community. Age and Ageing, 27, 4, 463-68.

*Ellis, K., Davis, A. and Rummery, K. I999. Needs assessment, street-level bureaucracy and the new community care. Social Policy and Administration, 33, 3, 262-8o.

*Enderby, P. 2002. Team working in community rehabilitation. Fournal of Clinical Nursing, I I $, 3,409-$ II.

*Gabbay, J., le May, A., Jefferson, H., Webb, D., Lovelock, R., Powell, J. and Lathlean, J. 2003. A case study of knowledge management in multi-agency consumer-informed 'communities of practice' : implications for evidence-based policy development in health and social services. Health, 7, 3, 283-310.

*Geddes, J. M. L. and Chamberlain, M. A. 200I. Home-based rehabilitation for people with stroke: a comparative study of six community services providing co-ordinated, multidisciplinary treatment. Clinical Rehabilitation, I 5, 6, 589-99.

Gibson, M.J., Gregory, S. R. and Pandya, S. M. 2003. Long-term Care in Developed Nations: A Brief Overview. Public Policy Institute, American Association of Retired People, Washington DC. Available online at http://www.aarp.org/research/ longtermcare/trends/aresearch-import-574-2003-I3.html [Accessed 20 December 2007].

*Glendinning, C. 2003. Breaking down barriers: integrating health and care services for older people in England. Health Policy, 65, 2, I39-5I.

*Glendinning, C., Coleman, A., Shipman, C. and Malbon, G. 20or. Progress in partnerships. British Medical Journal, 323, 7303, 28-31.

*Glendinning, C., Jacobs, S., Alborz, A. and Hann, M. $2002 a$. A survey of access to medical services in nursing and residential homes in England. British Fournal of General Practice, 52, 480, 545-8.

*Glendinning, C., Coleman, A. and Rummery, K. $2002 b$. Partnerships performance and primary care: developing integrated services for older people in England. Ageing $\mathcal{E}^{\circ}$ Society, 22, 2, 185-208.

*Goodman, C., Woolley, R. and Knight, D. 2003. District nurses' experiences of providing care in residential care home settings. Fournal of Clinical Nursing, I 2, I, $67-76$.

Gray, J. M. 1997. Evidence-based Healthcare: How to Make Health Policy and Management Decisions. Churchill Livingstone, London.

Griffiths, R. 1998. Community Care: An Agenda for Action. HMSO, London.

*Gross, B. and Caiden, M. 200o. The implications of aging in place for community-based services for elderly people. Care Management Fournal, 2, I, 2 I-6.

*Grundy, E. and Glaser, K. 1997. Trends in, and transitions to, institutional residence among older people in England and Wales, 1971-91. Fournal of Epidemiology and Community Health, 5I, 5, 53 I-40. 
*Hakim, E. A. and Bakheit, A. M. O. I998. A study of the factors which influence the length of hospital stay of stroke patients. Clinical Rehabilitation, I 2, 2, I5 ${ }^{\mathrm{I}-6 .}$

*Hallewell, C., Morris, J. and Jolley, D. i994. The closure of residential homes: what happens to residents. Age and Ageing, 23, 2, I58-6I.

*Hancock, G. A., Reynolds, T., Woods, B., Thornicroft, G. and Orrell, M. 2003. The needs of older people with mental health problems according to the user, the carer, and the staff. International fournal of Geriatric Psychiatry, I 8, 9, 803-I I.

*Hardy, B., Young, R. and Wistow, G. I999. Dimensions of choice in the assessment and care management process: the views of older people, carers and care managers. Health and Social Care in the Community, 7, 6, 483-9I.

Health and Social Care Information Centre 2006. Personal Social Services Expenditure and Unit Costs: England: 2004-2005. Health and Social Care Information Centre, London Available online at http://www.ic.nhs.uk/webfiles/publications/persocservexp2005/ PSSExpenditure020206_PDF.pdf [Accessed io November 2008].

Hood, C. r99. A public management for all seasons? Public Administration, 69, I, 3-I9.

*Hughes, J., Stewart, K., Challis, D., Darton, R. and Weiner, K. 200r. Care management and the care programme approach: towards integration in old age mental health services. International Fournal of Geriatric Psychiatry, I6, 3, 266-72.

Hussein, S. and Manthorpe, J. 2005. An international review of the long-term care workforce: policies and shortages. Fournal of Aging and Social Policy, I 7, 4, 75-94.

Huxley, P. 1993. Case management and care management in community care. British Journal of Social Work, 23, 4, 365-81.

Ikegami, N., Yamauchi, K. and Yamada, Y. 2003. The long-term care insurance law in Japan: impact on institutional care facilities. International Fournal of Geriatric Psychiatry, $\mathbf{~ 8 ,}$ $3,2 \mathrm{I} 7-2 \mathrm{I}$.

*Iliffe, S., Tai, S. S., Haines, A., Gallivan, S., Goldenberg, E., Booroff, A. and Morgan, P. I992. Are elderly people living alone an at risk group? British Medical Fournal, 305, 686o, IOOI- 4 .

Intermediate Care National Evaluation Team 2006. A National Evaluation of the Costs and Outcomes of Intermediate Care for Older People: Executive Summary. Universities of Birmingham and Leicester, Birmingham and Leicester, UK. Available online at http://www.hsmc. bham.ac.uk/programmes/partnership.htm [Accessed 24 May 2006].

ISI ResearchSoft 200I. Reference Manager Version Io for Windows. Thomson Scientific, Philadelphia, Pennsylvania. Available online at http://www.refman.com/support/ docs/User\%20Manual\%2oRMio.pdf [Accessed i8 November 2008].

*Jacobs, S. 2003. Addressing the problems associated with general practitioners' workload in nursing and residential homes: findings from a qualitative study. British Fournal of General Practice, 53, 487, II3-9.

*Jacobs, S. and Rummery, K. 2002. Nursing homes in England and their capacity to provide rehabilitation and intermediate care services. Social Policy and Administration, 36, 7, $735^{-52 .}$

Jacobzone, S. 200o. Coping with aging: international challenges. Health Affairs, r 9, 3, 213-25.

Johnson, P., Wistow, G., Schulz, R. and Hardy, B. 2003. Interagency and interprofessional collaboration in community care: the interdependence of structures and values. Fournal of Interprofessional Care, I 7, I, 69-83.

Johri, M., Beland, F. and Bergman, H. 2003. International experiments in integrated care for the elderly: a synthesis of the evidence. International Fournal of Geriatric Psychiatry, $\mathbf{~ 8 , ~ 3 , ~}$ 222-35.

*Kirchner, V., Elloy, M. D., Silver, L. E. and Kelly, C. A. 200o. Dementia: the cost of care for behaviourally disturbed patients living in the community. International fournal of Geriatric Psychiatry, I5, II, I000-4. 
*Koffman, J., Fulop, N. J., Pashley, D. and Coleman, K. I996. No way out: the delayed discharge of elderly mentally ill acute and assessment patients in north and south Thames regions. Age and Ageing, 25, 4, 268-72.

*Leece, J. 2001. Direct support: direct payments and older people. Generations Review: Journal of the British Society of Gerontology, I I , 3, 23-5.

Leichsenring, K. 2003. Providing Integrated Health and Social Care for Older Persons: A European Overview. European Centre for Social Welfare Policy and Research, Vienna. Available online at http://www.imsersomayores.csic.es/documentos/documentos/ procare-providingeurope-or.pdf [Accessed 20 December 2007]

*Lewis, P. A., Dunn, R. B. and Vetter, N. J. I994. NHS and Community Care Act 1990 and discharges from hospital to private residential and nursing homes. British Medical Fournal, 309, 6946, 28-9.

*Lindesay, J., Jagger, C., Hibbett, M. J., Peet, S. M. and Moledina, F. I997. Knowledge, uptake and availability of health and social services among Asian Gujarati and white elderly persons. Ethnicity and Health, 2, I/2, 59-69.

*Livingston, G., Manela, M. and Katona, C. I997. Cost of community care for older people. British fournal of Psychiatry, I 7 I, I, 56-9.

*Livingston, G., Leavey, G., Kitchen, G., Manela, M., Sembhi, S. and Katona, C. 2002. Accessibility of health and social services to immigrant elders: the Islington study. British Fournal of Psychiatry, $\mathbf{1 8 0}, 4,369-73$.

*Lloyd, M. 200o. Where has all the care management gone? The challenge of Parkinson's disease to the health and social care interface. British Fournal of Social Work, 3o, 6, 737-54.

*MacDonald, L. D., Higgs, P. F. D., MacDonald, J. S., Godfrey, E. L. and Ward, M. C. I996. Carers' reflections on nursing home and NHS long-stay care for elderly patients. Health and Social Care in the Community, 4, 5, 264-70.

*MacPherson, I., Donald, S. and Ludbrook, A. I992. Registered private nursing homes in Scotland: referral and assessment practice. Age and Ageing, 2 I, 6, 429-34.

*Manthorpe, J. and Alaszewski, H. 2002. Listening to the dementia workforce: local providers' perceptions of dementia services. Quality in Ageing, 3, 2, 22-9.

*Martin, M., Pehrson, J. and Orrell, M. i999. A survey of social services needs assessments for elderly mentally ill people in England and Wales. Age and Ageing, 28, 6, 575-7.

*McLeod, E., Bywaters, P. and Cooke, M. 2003. Social work in accident and emergency departments: a better deal for older patients' health? British Journal of Social Work, 33, 6, 787-802.

*McNamee, P., Christensen, J., Soutter, J., Rodgers, H., Craig, N., Pearson, P. and Bond, J. 1998. Cost analysis of early supported hospital discharge for stroke. Age and Ageing, 27, $3,345^{-5}$ I.

*McNamee, P., Gregson, B. A., Buck, D., Bamford, C. H., Bond, J. and Wright, K. I999. Costs of formal care for frail older people in England: the resource implications study of the MRG Cognitive Function and Ageing Study (RIS MRC CFAS). Social Science and Medicine, 48, 3, 33 I-4I.

Mays, N. and Pope, C. 200o. Qualitative research in health care: assessing quality in qualitative research. British Medical fournal, 320, 7226, 50-2.

Mays, N., Roberts, E. and Popay, J. 20or. Synthesising research evidence. In Fulop, N. Allen, P., Clarke, A and Black, N. (eds), Studying the Organisation and Delivery of Health Services: Research Methods. Routledge, London, I88-220.

*Millard, P. H., Christodoulou, G., Jagger, C., Harrison, G. W. and McClean, S. I. 200 I. Modelling hospital and social-care bed occupancy and use by elderly people in an English health district. Health Care Management Science, 4, I, 57-62.

*Nelson, T., Livingston, G., Knapp, M., Manela, M., Kitchen, G. and Katona, C. 2002. Slicing the health service cake: the Islington study. Age and Ageing, 31 , 6, 445-50. 
*Nelson, T., Fernandez, J. L., Livingston, G., Knapp, M. and Katona, C. 2004. Does diagnosis determine delivery? The Islington study of older people's needs and health care costs. Psychological Medicine, 34, I, I47-55.

*Netten, A. I992. A positive experience? Assessing the effect of the social environment on demented elderly residents of local authority homes. Social Work and Social Sciences Review, 3, I, 46-62.

*Netten, A., Darton, R., Bebbington, A. and Brown, P. 200I. Residential or nursing home care? The appropriateness of placement decisions. Ageing \& Society, 2 I, I, 3-23.

*Netten, A., Darton, R. and Williams, J. 2003. Nursing home closures: effects on capacity and reasons for closure. Age and Ageing, 32, 3, 332-7.

*Netten, A. and Darton, R. 2003. The effect of financial incentives and access to services on self-funded admissions to care homes. Social Policy and Administration, 37, 5, $483-97$.

Newman, J. 200i. Modernising Governance: New Labour, Policy and Society. Sage, London.

*Newnham, D. M., Berrington, A., Primrose, W. R. and Seymour, D. G. i996. Selffunding and community care admissions to nursing homes in Aberdeen. Health Bulletin, $\mathbf{5 4}, 4,3 \mathrm{OI}-6$.

*O'Dea, G., Kerrison, S. H. and Pollock, A. M. 2000. Access to health care in nursing homes: a survey in one English Health Authority. Health and Social Care in the Community, 8, 3, 180-5.

Organisation for Economic Co-operation and Development (OECD) 2003. Public Sector Modernisation. Policy Brief, OECD, Paris. Available online at http://www.oecd.org/ dataoecd/63/23/I5688578.pdf [Accessed io November 2008].

*Parry-Jones, B. and Soulsby, J. 2001. Needs-led assessment: the challenges and the reality. Health and Social Care in the Community, 9, 6, 414-28.

*Penrice, G. M., Simpson, L., de Caestecker, L., Brown, G. and Gillies, S. 200 I. Low dependency residents in private nursing homes in Glasgow. Health Bulletin, 59, I, I5-20.

Petticrew, M. and Roberts, H. 2003. Evidence, hierarchies and typologies: horses for courses. Fournal of Epidemiology and Community Health, 57, 7, 527-9.

*Philp, I., McKee, K. J., Meldrum, P., Ballinger, B. R., Gilhooly, M. L., Gordon, D. S., Mutch, W.J. and Whittick, J. E. I995. Community care for demented and nondemented elderly people: a comparison study of financial burden, service use, and unmet needs in family supporters. British Medical fournal, 310, 6993, I503-6.

*Pollitt, P. A., Anderson, I. and O'Connor, D. W. I99I. For better or for worse: the experience of caring for an elderly dementing spouse. Ageing \& Society, I I, 4, 443-69.

*Postle, K. 2002. Working 'between the idea and the reality': ambiguities and tensions in care managers' work. British Fournal of Social Work, 32, 3, 335-51.

*Powell, J. 2000. Goal negotiation with older people in three day-care settings. Health and Social Care in the Community, 8, 6, 380-9.

*Proctor, R., Burns, A., Stratton Powell, H., Tarrier, N., Faragher, B., Richardson, G., Davies, L. and South, B. I999. Behavioural management in nursing and residential homes: a randomised controlled trial. The Lancet, 354, 9172, 26-9.

*Qureshi, H. I999. Outcomes of social care for adults: attitudes towards collecting outcome information in practice. Health and Social Care in the Community, 7, 4, 257-65.

*Reed, J. and Stanley, D. 2003. Improving communication between hospitals and care homes: the development of a daily-living plan for older people. Health and Social Care in the Community, I I , 4, 356-63.

*Reed, J., Cook, G., Sullivan, A. and Burridge, C. 2003. Making a move: care-home residents' experiences of relocation. Ageing \& Society, 23, 2, 225-4I.

*Reid, D., Ryan, T. and Enderby, P. 20or. What does it mean to listen to people with dementia? Disability and Society, I6, 3, 377-92. 
*Reilly, S., Challis, D., Burns, A. and Hughes, J. 2003. Does integration really make a difference? A comparison of old-age psychiatry services in England and Northern Ireland. International Fournal of Geriatric Psychiatry, 18, I0, 887-93.

Reilly, S., Xie, C., Jacobs, S. and Challis, D. 2008. Examining the state of adult social care research I990-200I: a systematic synthesis of research methods and quality. Evidence and Policy, 4, 3, I55-82.

Rhodes, R. A. W. 200o. The governance narrative: key findings and lessons from the ESRC's Whitehall programme. Public Administration, 78, 2, 345-63.

*Richards, S. 2000. Bridging the divide: elders and the assessment process. British fournal of Social Work, 3o, I, 37-49.

*Richardson, G., Davies, L., South, B., Proctor, R., Burns, A., Powell, H. S., Tarrier, N. and Faragher, B. 2000. Economic impact of a specialist outreach team in residential and nursing home settings. Fournal of Mental Health Policy and Economics, 3, 3, I47-52.

*Robinson, L. and Drinkwater, C. 200o. Care of the frail elderly in the community: a critical incident study. Primary Health Care Research and Development, I, 3, I63-77.

*Ross, F. and Tissier, J. I997. The care management interface with general practice: a case study. Health and Social Care in the Community, 5, 3, I53-I6I.

*Rummery, K. and Coleman, A. 2003. Primary health and social care services in the UK: progress towards partnership? Social Science and Medicine, 56, 8, I773-82.

*Rothera, I., Jones, R., Harwood, R., Avery, A. J. and Waite, J. 2003. Health status and assessed need for a cohort of older people admitted to nursing and residential homes. Age and Ageing, 32, 3, 303-9.

*Rummery, K., Ellis, K. and Davis, A. I999. Negotiating access to community care assessments: perspectives of front-line workers, people with a disability and carers. Health and Social Care in the Community, 7, 4, 296-300.

*Rummery, K. and Coleman, A. 2003. Primary health and social care services in the UK: progress towards partnership? Social Science and Medicine, 56, 8, I773-82.

*Schneider, J., Hallam, A., Murray, J., Foley, B., Atkin, L., Banerjee, S., Islam, M. K. and Mann, A. H. 2002. Formal and informal care for people with dementia: factors associated with service receipt. Aging and Mental Health, 6, 3, 255-65.

*Schneider, J., Hallam, A., Islam, M. K., Murray, J., Foley, B., Atkins, L., Banerjee, S. and Mann, A. H. 2003. Formal and informal care for people with dementia: variations in costs over time. Ageing \& Society, 23, 3, 303-26.

Social Services Inspectorate (SSI) 1987. From Home Help to Home Care: An Analysis of Policy Resourcing and Service Management. SSI, London.

Social Services Inspectorate and Social Work Services Group (SSI/SWSG) i99 a $a$. Care Management and Assessment: Manager's Guide. SSI/SWSG, HMSO, London.

Social Services Inspectorate and Social Work Services Group i99I b. Care Management and Assessment: Practitioner's Guide. SSI/SWSG, HMSO, London.

Spencer, L., Ritchie, J., Lewis, J. and Dillon, L. 2003. Quality in Qualitative Evaluation: A Framework for Assessing Research Evidence. Chief Social Researcher's Office, London.

*Stern, M. C., Jagger, C., Clarke, M., Anderson, J., McGrother, C., Battock, T. and McDonald, C. 1993. Residential care for elderly people: a decade of change. British Medical Journal, 306, 688I, 827-30.

*Stewart, K., Challis, D., Carpenter, I. and Dickinson, E. I999. Assessment approaches for older people receiving social care: content and coverage. International foumal of Geriatric Psychiatry, 14, 2, 147-56.

*Stoddart, H., Whitley, E., Harvey, I. and Sharp, D. 2002. What determines the use of home care services by elderly people? Health and Social Care in the Community, ro, 5, 348-6o.

*Tanner, D. 20or. Sustaining the self in later life: supporting older people in the community. Ageing \& Society, 2 I , 3, 255-78. 
*Taylor, P. 200I. Meeting the holistic needs of older people in the community: an examination of a new generic health and social care worker role. Local Governance, 27, 4, 239-46.

*Temple, B., Glenister, C. and Raynes, N. 2002. Prioritising home care needs: research with older people from three ethnic minority community groups. Health and Social Care in the Community, I0, 3, I79-86.

Townsend, P. I98I. The structured dependency of the elderly: a creation of social policy in the twentieth century. Ageing E्E Society, I, I, 5-28.

*Trieman, N., Wills, W. and Leff, J. I996. TAPS Project 28: does reprovision benefit elderly long-stay mental patients? Schizophrenia Research, 2 I, 3, I99-208.

Ungerson, C. 2004. Whose empowerment and independence? A cross-national perspective on 'cash for care' schemes. Ageing \&' Society, 24, 2, 189-212.

Vetter, N. J. 2005. Intermediate care: policy before evidence. British Medical fournal, 33 I, 320.

*Victor, C. R., Healy, J., Thomas, A. and Seargeant, J. 200o. Older patients and delayed discharge from hospital. Health and Social Care in the Community, 8, 6, 443-52.

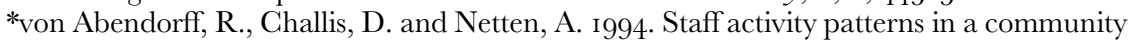
mental health team for older people. International Fournal of Geriatric Psychiatry, 9, in, 897-9o6.

*Walker, M., Orrell, M., Manela, M., Livingston, G. and Katona, C. I998. Do health and use of services differ in residents of sheltered accommodation? A pilot study. International Fournal of Geriatric Psychiatry, 13, 9, 6r7-24.

Ware, P., Matosevic, T., Forder, J., Hardy, B., Kendall, J., Knapp, M. and Wistow, G. 200I. Movement and change: independent sector domiciliary care providers between I995 and 1999. Health and Social Care in the Community, 9, 6, 334-40.

*Ware, T., Matosevic, T., Hardy, B., Knapp, M., Kendall, J. and Forder, J. 2003. Commissioning care services for older people in England: the view from care managers, users and carers. Ageing \& Society, 23, 4, 4II-28.

*Warnes, A. M., Armstrong, G. K. and Peters, D. i997. Population predictors of community health and social service use in Northern Ireland. Fournal of Epidemiology and Community Health, 5I, 6, 722-30.

Warren, M. I946. Care of the aged chronic sick. The Lancet, 247, 6406, 84 ${ }^{-}-3$.

*Weinberg, A., Williamson, J., Challis, D. and Hughes, J. 2003. What do care managers do? A study of working practice in older peoples' services. British Journal of Social Work, 33, 7, 90I-I9.

*Weiner, K., Stewart, K., Hughes, J., Challis, D. and Darton, R. 2002. Care management arrangements for older people in England: key areas of variation in a national study. Ageing E Society, 22, 4, 4I9-39.

*Weiner, K., Hughes, J., Challis, D. and Pederson, I. 2003. Integrating health and social care at the micro level: health care professionals as care managers for older people. Social Policy and Administration, 37, 5, 498-515.

*Wenger, G. C. 1999. Choosing and paying for care. Health and Social Care in the Community, 7, 3, I87-97.

*Wills, W. and Leff, J. I996. The TAPS Project 30: quality of life for elderly mentally ill patients: a comparison of hospital and community settings. International Fournal of Geriatric Psychiatry, I I, I I, 953-63.

*Wills, W., Trieman, N. and Leff, J. I998. The TAPS Project 40: quality of care provisions for the elderly mentally ill: traditional vs. alternative facilities. International fournal of Geriatric Psychiatry, I3, 4, 225-34.

*Wittenberg, R., Pickard, L., Comas-Herrera, A. and Davies, B. 200ı. Demand for long-term care for older people in England to 2031. Health Statistics Quarterly, I3, Winter, $5^{-\mathrm{I} 7}$. 
*Wood, P. and Castleden, M. 1993. Dependency, quality and staffing of institutions for elderly people. Health Trends, 25, 3, 97-IOI.

*Wright, F. 1994. Multi-purpose residential homes: a fair deal for residents. Ageing E̊ Society, I 4, $3,383-404$.

*Wright, F. 2003. Discrimination against self-funding residents in long term residential care in England. Ageing \& Society, 23, 5, 603-24.

Address for correspondence:

Accepted I4 November 2008

Sally Jacobs, School of Pharmacy and Pharmaceutical Sciences, Ist floor, Stopford Building, University of Manchester, Oxford Road, Manchester Mi3 9 PT, UK

Email: sally.jacobs@manchester.ac.uk 